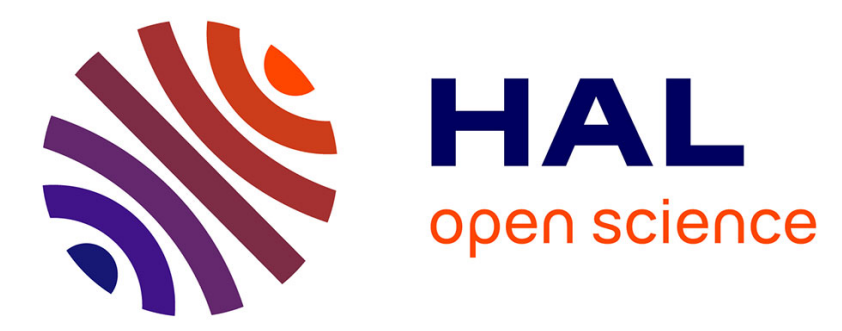

\title{
Late Middle Palaeolithic lithic technocomplexes (MIS 5-3) in the northeastern Aquitaine Basin: Advances and challenges
}

Jean-Philippe Faivre, Brad Gravina, Laurence Bourguignon, Emmanuel Discamps, Alain Turq

\section{To cite this version:}

Jean-Philippe Faivre, Brad Gravina, Laurence Bourguignon, Emmanuel Discamps, Alain Turq. Late Middle Palaeolithic lithic technocomplexes (MIS 5-3) in the northeastern Aquitaine Basin: Advances and challenges. Quaternary International, 2017, 433, pp.116-131. hal-02012793

\section{HAL Id: hal-02012793 \\ https://hal.science/hal-02012793}

Submitted on 3 Dec 2020

HAL is a multi-disciplinary open access archive for the deposit and dissemination of scientific research documents, whether they are published or not. The documents may come from teaching and research institutions in France or abroad, or from public or private research centers.
L'archive ouverte pluridisciplinaire HAL, est destinée au dépôt et à la diffusion de documents scientifiques de niveau recherche, publiés ou non, émanant des établissements d'enseignement et de recherche français ou étrangers, des laboratoires publics ou privés. 


\title{
Late Middle Palaeolithic lithic technocomplexes (MIS 5-3) in the northeastern Aquitaine Basin: Advances and challenges
}

\author{
J.-Ph. Faivre, B. Gravina, L. Bourguignon, E. Discamps, A. Turq
}

\section{Keywords:}

Lithic technology Mousterian

variability Technocomplex

Quina

Levallois

Discoid

\begin{abstract}
a b s t r a c t
Establishing and interpreting patterns of lithic assemblage variability is of great interest to archae- ologists as they shed light on cultural adaptations in the deep past. Nowhere has this topic provoked more interest and debate than in the Middle Palaeolithic of southwestern France. The region's rich archaeological record has produced numerous sites, many of which have been recently excavated and thus provide a reliable dataset for better structuring Mousterian lithic variability. Researchers working with these types of datasets frequently employ the chaîne operatoire concept to approach lithic assemblage variability; however, the validity of such analyses has recently been questioned. Here we present results of a combined quantitative and qualitative technological analysis of a large sample of assemblages from numerous well-contextualised sites in the northeastern Aquitaine Basin. We selected clearly identifiable diagnostic elements typical of different flake production systems that can be quantified by different analysts in a replicable fashion. Our results show strong differences in assemblage composition in terms of dominant production systems as well as a smaller number of mixed assemblages that combine two or more flake production methods. When considered together, these results provide not only a means for defining lithic technocomplexes and subse- quently comparing assemblages but also for investigating elements of Neanderthal material culture variability.
\end{abstract}

\section{Introduction}

The last decade has seen renewed and intense interest in Palaeolithic industrial variability, the definition of its constituent elements as well as their interpretation. While commonly associated with the Western European record, similar questions and problems are confronted by researchers around the world, resulting in varying approaches, each with a specific research history. Moreover, varying aspects of lithic assemblages are privileged, such as type fossils (e.g. Châtelperronian or Gravettian points), distinct technological (e.g. pressure flaking or the Levallois method) or quantitative features (e.g. numbers and sizes of tools) by different researchers for comparing assemblages. Underlying the selection of the most relevant comparative or interpretative elements lie clear conceptual differences that are at times difficult to articulate together. Even a cursory survey of recent literature concerning lithic analysis reveals what can best be described as 'different schools of thought' built from divergent research trajectories.

This heuristic divide is nowhere more evident than in the interpretation of Middle Palaeolithic assemblage variability, the choice of a proper analytical approach for comparing assemblages from this period, and the relative influence of climatic, environmental, biological, cultural, and demographic factors. These types of questions are of equal importance regardless of the study region, as similar discussions concern, for example, the Middle Stone Age record of North and South Africa, the Mousterian of the Near East and southwestern France, and, for more recent periods, the ethnographic record of Australia (Holdaway and Douglass, 2011). Southwestern France has played a fundamental role in the development of Palaeolithic systematics both in terms of typological aspects, for example, the so-called Bordesian method, as well as defining 
technological features of lithic assemblages. Its rich archaeological record has been the testing ground for numerous interpretive interpretations beginning with F. Bordes culture-historic 'five tribes' model (Bordes, 1953), which was almost immediately countered by chronological (Mellars, 1965, 1970, 1996) and functional models (Binford and Binford, 1966), followed by processual approaches that incorporated aspects of tool reduction (Dibble, 1987, 1995) and the influence of occupation intensity and changing climatic conditions (Rolland and Dibble, 1990; Dibble and Rolland, 1992). The relationship between climatic data and the economy of lithic raw material also focused attention on the interrelation between lithic assemblages and group mobility patterns. This situation led to inferences of differential mobility for certain raw materials and tool types or technologies (Geneste, 1985, 1988, 1991; Turq, 1989, 1990, 1992; Delagnes and Rendu, 2011). These models, while having clearly enriched our understanding of the possible factors underlying patterns observed in Middle Palaeolithic assemblages, have also led to conflicting interpretations, with each practitioner defending their position or, in extreme instances, highlighting the 'inutility' of certain methodological criteria for studying lithic assemblages (i.e. Monnier and Missal, 2014).

Important aspects concerning Palaeolithic systematics continue to be problematic, including confusion surrounding the emergent designation of archaeological assemblages as lithic techno-complexes (e.g. Delagnes et al., 2007; Jaubert et al., 2011; Jaubert et al., 2011) and the possible risk of plunging us into 'another Mousterian debate' (Monnier and Missal, 2014: our emphasis). While the actors have changed, disagreements concerning the degree to which climate, culture, form and function underlie the character of lithic assemblages remain effectively the same e in other words, the curtain never really closed on the original Mousterian debate of Bordes and Binford. From the mid 1980s onwards, the culturehistoricism underlying Bordes' 'facies' with its emphasis on retouched tool frequencies came to be replaced by a more holistic approach to lithic assemblage composition embodied in the chaîne opératoire concept (hereafter CO) and associated technological approaches (Tixier, 1978; Tixier et al., 1980; Cahen et al., 1980; Geneste, 1985, 1991; Boëda, 1986; Inizan et al., 1999). The CO approach moved attention away from retouched tools, focusing instead on the totality of a lithic assemblage. In doing so, assemblages were viewed from the perspective of the organisation of the different technical processes and actions responsible for the ultimate form of an artefact, its place within the reduction sequence, as well as the segmentation of actions in time and space (see Bleed, 2001; Bar-Yosef and Van Peer, 2009; Soressi and Geneste, 2011 for syntheses).

In parallel, the last decade has seen the development of alternative methods of lithic analysis based on the statistical treatment of quantitative and categorical attributes (e.g. Brantingham and Kuhn, 2001; Tostevin, 2003, 2012; Dibble and Rezek, 2009; Lycett and Eren, 2013; Scerri et al., 2015). Lithic analysts working within these alternative analytical paradigms have contested the ability of technological studies, more specifically, the validity of the $\mathrm{CO}$ approach, for investigating and interpreting lithic assemblage variability. Certain researchers have gone so far as describing the identification of particular end-products, the attribution of elements to a specific reduction phase, or the ability of such approaches to track cultural trends as a 'fallacy' based on 'intuition' (Monnier and Missal, 2014:61). Thus, the core issue at hand for palaeoanthropology appears to be the choice of the most appropriate methodology for both analysing and best comparing lithic assemblages.
The opinion that technological analyses boil down to 'intuition' neglects the fact that, as with other methods, the $\mathrm{CO}$ approach can infuse interpretations with quantitative data acquired in a reproducible fashion. The CO approach frequently uses refitting and experimentation data to characterise assemblages and facilitate their comparison. In order to move the debate forward and answer to critics, we 1) selected common diagnostic technological elements that can be securely identified by different analysts and 2) tested if statistical analysis of the proportions of these elements in a selected region, the north-eastern Aquitaine Basin of southwestern France, over a given period (MIS 5-3), highlights differences between assemblages that are coherent with previous research performed within a $\mathrm{CO}$ framework. The selected study region has produced amongst the highest densities of recently excavated Middle Palaeolithic enclosed and open-air sites anywhere in the world. Nearly four decades of technological analyses, experimentation, and refitting combined with comprehensive raw material surveys create an ideal testing ground for exploring the structure of Mousterian lithic assemblage variability. Finally, we conclude by reflecting on the present and future role of lithic technology in material culture studies.

\section{Material and methods}

The northeastern Aquitaine Basin is limited by the Garonne Valley to the south, the Dronne Valley to the north and the Massif Central in the northeast. This region includes a varied topography and numerous hydrological networks centered around four main rivers, the Isle, Dordogne, Lot and Garonne and their tributaries (Fig. 1). The sample includes 41 assemblages from 24 Middle Palaeolithic sites, including caves and rock-shelters as well as open-air occupations, which were either recently excavated or revised and for which the artificial mixing of material from different layers can be ruled out. Table 1 presents the dominant group of retouched tools for each assemblage alongside associated flake production system described by previous $\mathrm{CO}$ analyses as either exclusive or mixed. We focused our analysis on a sub-sample of 24 assemblages for which detailed technological counts are available (Table 2). The dataset was explored using correspondence analysis performed with the PAST software package on artefact numbers for 7 specifically chosen technological artefact types that are best suited for inter-assemblage comparisons (see below).

In addition to assemblage size and proportion of retouched tools for each context studied, we quantified products belonging to seven specific, consistently identifiable technological categories typical of welldocumented Middle Palaeolithic flake production methods. The first and second categories comprise Levallois flakes and cores (Fig. 2). The Levallois method produces predetermined removals according to specific recurrent modalities (unipolar, bipolar, centripetal, convergent; e.g. Boëda, 1986, 1994; Geneste, 1988; Boëda et al., 1990; Delagnes, 1992; Van Peer, 1992; articles in Dibble and Bar Yosef, 1995; Lycett and Eren, 2013) or a single flake for preferential or lineal modalities (Boëda, 1986). The Levallois products identified in the studied assemblages therefore correspond to a wide range of sizes and shapes (e.g. elongated, triangular, quadrangular) that clearly result from Levallois flaking methods as evidence by associated cores.

The third and fourth category includes pieces with a thick 'back' that corresponds to a removed portion of the lateral edge of the core. This 'back' may retain a combination of contrabulbs, flake negatives or cortical portions (Locht and Swinnen, 1994; Mourre and Jaubert, 1996; Pasty, 2000; Peresani, 2003). 
Table 1

Technological and typological data for the overall Middle Palaeolithic assemblage sample.

\begin{tabular}{|c|c|c|c|c|c|c|}
\hline Site & Layer $^{\mathrm{a}}$ & $\begin{array}{l}\text { Previous technological } \\
\text { attribution }^{\mathrm{b}}\end{array}$ & $\begin{array}{l}\text { Evidence for } \\
\text { bifacial shaping }\end{array}$ & $\begin{array}{l}\text { Dominant retouched } \\
\text { tool type }{ }^{c}\end{array}$ & $\begin{array}{l}\text { Included } \\
\text { in statistical } \\
\text { analyses }\end{array}$ & References \\
\hline Cantalouette IV & 2 & Lev & Yes & $\mathrm{S}$ & $\mathrm{x}$ & Blaser et al., 2012 \\
\hline Moustier G1/G2 & $\mathrm{G} 1 / \mathrm{G} 2$ & Lev & Yes & $\mathrm{S}$ & $\mathrm{x}$ & $\begin{array}{l}\text { Gravina and Discamps, 2015; } \\
\text { Gravina, in press }\end{array}$ \\
\hline Corbiac & M1-M2-M3 & Lev & Yes & $\mathrm{S}$ & & This study \\
\hline Toutifaut & - & Lev & Yes & $\mathrm{S}$ & & This study \\
\hline La Plane & - & Lev & Yes & $\mathrm{S}$ & & Turq, 2000 \\
\hline La Ferrassie & 4 & Lev & No & $\mathrm{S}$ & & This study \\
\hline Chemin d'Herbe & - & Lev & Yes & $\mathrm{S}$ & $\mathrm{X}$ & Brenet, 2012 \\
\hline Caminade Est & M1/M2 & Lev & No & $\mathrm{S}$ & & Perinotto, 2015 \\
\hline Roc de Marsal & $\mathrm{XI}$ & Quina & Yes & $\mathrm{S}$ & $\mathrm{X}$ & Turq, 1992 \\
\hline Roc de Marsal & $\mathrm{X}$ & Quina & Yes & $\mathrm{S}$ & $\mathrm{X}$ & Turq, 1992 \\
\hline Roc de Marsal & IX & Quina & Yes & $S$ & $\mathrm{X}$ & Turq, 1992 \\
\hline Combe-Grenal & 17 & Quina & No & $\mathrm{S}$ & $\mathrm{X}$ & Faivre, 2011 \\
\hline Combe-Grenal & 20 & Quina & No & $N \& D$ & $\mathrm{X}$ & Faivre, 2008 \\
\hline Caminade Est & M3 & Quina & No & $\mathrm{S}$ & & Perinotto, 2015 \\
\hline Combe-Capelle bas & $\mathrm{I}-1 \mathrm{~b}-\mathrm{c}$ & Quina & No & $N \& D$ & & $\begin{array}{l}\text { Dibble and Lenoir, } 1995 \\
\text { Turq, } 2000\end{array}$ \\
\hline Moulin du Milieu & - & Quina & No & $\mathrm{S}$ & & Turq, 2000 \\
\hline Moustier & $\mathrm{H} 2-\mathrm{H} 9$ & Crd Disc & Yes & $N \& D$ & $\mathrm{X}$ & Gravina and Discamps, 2015 \\
\hline Champs de Bossuet & - & Crd Disc & No & $N \& D$ & $\mathrm{X}$ & Bourguignon and Turq, 2003 \\
\hline Combe Grenal & 14 & Crd Disc & No & N\&D & $\mathrm{X}$ & Bourguignon and Turq, 2003 \\
\hline Les Fieux & G7 & Crd Disc + Ctp Disc & No & $N \& D$ & & Faivre, 2004 \\
\hline Les Fieux & $\mathrm{I}-\mathrm{J}(\mathrm{S})$ & Crd Disc & No & $N \& D$ & $\mathrm{X}$ & Faivre, 2011 \\
\hline Roc de Combe & Zone $2(\mathrm{~S})$ & Crd Disc & No & $N \& D$ & $\mathrm{x}$ & Lorenzo Martinez et al., 2014 \\
\hline Roc de Combe & Zone $2(\mathrm{Q})$ & Crd Disc & No & $N \& D$ & $\mathrm{X}$ & Lorenzo Martinez et al., 2014 \\
\hline Regourdou & 4 & Crd Disc & No & N\&D & $\mathrm{x}$ & This study \\
\hline Bouffia 118 & - & Crd Disc & No & $N \& D$ & & Rendu et al., 2014; this study \\
\hline Les Fieux & $\mathrm{K}(\mathrm{S})$ & Crd Disc & No & $N \& D$ & $\mathrm{X}$ & Thiébaut et al., 2009 \\
\hline Les Fieux & $\mathrm{Ks}(\mathrm{Q})$ & Ctp Disc & No & $\mathrm{S}$ & & Faivre, 2003, 2006 \\
\hline Cantalouette IV & 1 & Lev + n-L lam & Yes & $\mathrm{S}$ & $\mathrm{X}$ & Blaser et al., 2012 \\
\hline Abri du Musée & - & $\mathrm{Lev}+\mathrm{n}-\mathrm{L}$ lam & Yes & $\mathrm{S}$ & $\mathrm{x}$ & $\begin{array}{l}\text { Bourguignon and Morala, in press; } \\
\text { Detrain et al., } 1991\end{array}$ \\
\hline Combe Brune 1 & 1 & Lev + n-L lam & Yes & $\mathrm{S}$ & $\mathrm{x}$ & Bourguignon et al., 2011a,b \\
\hline Combe-Grenal & $29 / 30$ & Lev + n-L lam + Crd Disc & No & $\mathrm{S}$ & $\mathrm{X}$ & Faivre, 2011, 2012 \\
\hline Vieux Coutet & 3 & Lev + Crd Disc & Yes & $\mathrm{S}$ & $\mathrm{X}$ & Bourguignon et al., 2004a,b \\
\hline Combe-Grenal & 27 & Lev + Crd Disc + n-L lam & No & $\mathrm{S}$ & $\mathrm{X}$ & Faivre, 2008 \\
\hline Combe-Grenal & 12 & Crd Disc + Lev + n-L lam & No & N\&D & $\mathrm{x}$ & Faivre, 2008 \\
\hline Pech de l'Azé IV & $3 a-3 b$ & Crd Disc + Lev & Yes & $N \& D$ & & $\begin{array}{l}\text { McPherron and Dibble, 1999; } \\
\text { Turq et al., } 2009\end{array}$ \\
\hline Combemenue & $-(\mathrm{S})$ & Lev & No & $\mathrm{S}$ & & Brenet, 2012 \\
\hline Combemenue & $-(Q)$ & Ctp Disc & No & $\mathrm{S}$ & & Brenet, 2012 \\
\hline Les Fieux & $\mathrm{K}(\mathrm{Q})$ & Ctp Disc + bipanv & Yes & $N \& D$ & $\mathrm{X}$ & Thiébaut et al., 2009 \\
\hline Les Fieux & $\mathrm{Ks}(\mathrm{S})$ & Lev & Yes & $\mathrm{S}$ & & Faivre, 2006 \\
\hline Pech de l'Azé 1 & 4 & EUF + Lev & Yes & $S$ & & Soressi, 2002; Faivre, 2003 \\
\hline Cantalouette 2 & - & UF + Lev & Yes & $\mathrm{S}$ & & Bourguignon et al., 2008 \\
\hline
\end{tabular}

a (S): flint artefacts; (Q): quartz artefacts.

b Lev: Levallois; n-L lam: non-Levallois laminar; Crd Disc: Cordal Discoid; Ctp Disc: Centripetal Discoid; bipanv: bipolar on anvil; Shap: bifacial shaping; UF: unipolar flaking; EUF: elongated unipolar flaking method.

c S: scraper; N\&D: notches and denticulates.

As originally defined by Boëda (1993), these products are detached along a chordal orientation meaning that their flaking or technological axisis oblique to the axis of the piece. We distinguish two types of chordal flakes. The first (Fig. 2, $\mathrm{n}^{\circ} 8-14$ ) have a distal point created by the intersection of two either unilineal or crossed removals opposite the 'back', referred to as a "pseudo-Levallois point" by Bordes (1961), while the second type (Fig. 2, $\mathrm{n}^{\circ}$ 15-18), termed éclat débordant, has a lateral back oriented along the technological axis of the flake that is opposite one or two edges. Although both the Levallois and Discoid methods produce pseudoLevallois points and éclats débordants, they are significantly more abundant and thicker in Discoid assemblages (see below).

The fifth category corresponds to cores fulfilling the techno- logical features of the Discoid method (e.g. Boëda, 1993; Peresani, 2003). These cores have a single (unifacial) surface (Fig. 3, $\mathrm{n}^{\circ} 1$ ) or at least two (bifacial or multidirectional) opposed surfaces (Fig. 3, $\mathrm{n}^{\circ} 3$ ) formed by a series of secant, primarily obliquely oriented removals that are both predetermined and predetermining and simultaneously maintain the necessary surface convexities.
Certain raw materials, particularly metaquartzites, are more often associated with the unifacial modality or bipolar percussion (Fig. 3, n ${ }^{\circ} 4$ 6).

The sixth category corresponds to large asymmetrical flakes (in section or profile) with thick, large cortical or flat platforms typical of the Quina flaking method (Turq, 1989; Bourguignon, 1996, 1997; Faivre, 2008, Hiscock et al., 2009; Fig. 4, $\left.\mathrm{n}^{\circ} 1-7\right)$. Despite their asymmetry, these flakes clearly differ morphologically from the chordal flakes described above (Turq, 1989; Bourguignon, 1996, 1997, Fig. 4, $\mathrm{n}^{\circ}$ 1-7). The substantial volume of these pieces potentially permits both long tool reduction sequences (i.e. sharpening, resharpening, Fig. $4, \mathrm{n}^{\circ} 8-10$ ) and act as a raw material reserve for producing additional flakes (Fig. $4, \mathrm{n}^{\circ} 11$ ). 
Assemblage sizes, retouched tool proportions and counts of different technological groups of the analysed assemblages included in the correspondence analysis.

\begin{tabular}{|c|c|c|c|c|c|c|c|c|c|c|c|c|}
\hline Code & Sites & Layer & $\% \mathrm{RT}^{1}$ & $\mathrm{AS}^{2}$ & Nb Lev $\mathrm{f}^{3}$ & $\mathrm{Nb}$ Lev $\mathrm{c}^{4}$ & $\mathrm{Nb} p-\mathrm{Lp}^{5}$ & $\mathrm{Nb} \mathrm{ED}^{6}$ & Nb Disc c ${ }^{7}$ & $\mathrm{Nb} Q-\mathrm{t} \mathrm{f}^{8}$ & Nb n-L lam ${ }^{9}$ & References \\
\hline AdM & Abri du Musée & - & $9.2 \%$ & 4122 & 562 & 103 & 0 & 785 & 0 & 0 & 6 & $\begin{array}{l}\text { Bourguignon and Morala, } \\
\text { in press; } \\
\text { Detrain et al., } 1991\end{array}$ \\
\hline CantIV-1 & Cantalouette IV & 1 & $6 \%$ & 364 & 36 & 14 & 2 & 15 & 0 & 0 & 100 & Blaser et al., 2012 \\
\hline CantIV-2 & Cantalouette IV & 2 & $2 \%$ & 182 & 11 & 2 & 0 & 15 & 0 & 0 & 0 & Blaser et al., 2012 \\
\hline $\mathrm{ChB}$ & $\begin{array}{l}\text { Champs de } \\
\text { Bossuet }\end{array}$ & 0 & $2.9 \%$ & 10,692 & 0 & 0 & 926 & 1661 & 820 & 0 & 0 & Bourguignon and Turq, 2003 \\
\hline $\mathrm{ChH}$ & Chemin d'Herbe & - & $7.4 \%$ & 335 & 43 & 8 & 7 & 5 & 0 & 0 & 0 & Brenet, 2012 \\
\hline CB1 & Combe Brune 1 & 1 & $12.2 \%$ & 524 & 77 & 18 & 4 & 111 & 0 & 1 & 11 & Bourguignon et al., 2011a,b \\
\hline CG-12 & Combe Grenal & 12 & $6 \%$ & 1671 & 17 & 3 & 148 & 158 & 24 & 0 & 26 & Faivre, 2008 \\
\hline CG-14 & Combe Grenal & 14 & 1.9 & 2885 & 0 & 0 & 174 & 543 & 386 & 0 & 0 & Bourguignon and Turq, 2003 \\
\hline CG-17 & Combe Grenal & 17 & $13.5 \%$ & 3060 & 0 & 0 & 8 & 163 & 0 & 323 & 0 & Faivre, 2011 \\
\hline CG-20 & Combe Grenal & 20 & $12 \%$ & 1578 & 0 & 0 & 9 & 28 & 0 & 448 & 0 & Faivre, 2008 \\
\hline CG-27 & Combe Grenal & 27 & $24 \%$ & 2220 & 400 & 26 & 86 & 42 & 11 & 0 & 19 & Faivre, 2008 \\
\hline CG-29/30 & Combe Grenal & $29 / 30$ & $12 \%$ & 4138 & 515 & 54 & 136 & 59 & 3 & 0 & 295 & Faivre, 2011 \\
\hline $\mathrm{F}-\mathrm{I} / \mathrm{J}(\mathrm{S})$ & Les Fieux & $\mathrm{I} / \mathrm{J}(\mathrm{S})$ & $3 \%$ & 1000 & 0 & 0 & 256 & 112 & 19 & 0 & 0 & Faivre, 2011 \\
\hline $\mathrm{F}-\mathrm{K}(\mathrm{S})$ & Les Fieux & $\mathrm{K}(\mathrm{S})$ & $6.4 \%$ & 288 & 0 & 0 & 22 & 40 & 12 & 0 & 0 & Thiébaut et al., 2009 \\
\hline $\mathrm{F}-\mathrm{K}(\mathrm{Q})$ & Les Fieux & $K(Q)$ & $2 \%$ & 277 & 0 & 0 & 17 & - & 15 & 0 & 0 & Thiébaut et al., 2009 \\
\hline Mo-G1-2 & Moustier & G1-G2 & $1.7 \%$ & 2787 & 94 & 8 & 25 & 127 & 1 & 0 & 0 & $\begin{array}{l}\text { Gravina and Discamps, 2015; } \\
\text { Gravina, in press }\end{array}$ \\
\hline Mo-H2-9 & Moustier & $\mathrm{H} 2-\mathrm{H} 9$ & $2.2 \%$ & 4722 & 1 & 0 & 235 & 264 & 28 & 0 & 0 & Gravina and Discamps, 2015 \\
\hline REG & Regourdou & 4 & $2.5 \%$ & 68 & 0 & 0 & 10 & 10 & 6 & 0 & 0 & This study \\
\hline $\operatorname{RdC}(S)$ & Roc de Combe & $\mathrm{Z2}(\mathrm{S})$ & $8.2 \%$ & 4910 & 0 & 0 & 254 & 376 & 225 & 0 & 0 & Lorenzo Martinez et al., 2014 \\
\hline $\operatorname{RdC}(Q)$ & Roc de Combe & $\mathrm{Z} 2(\mathrm{Q})$ & $2.9 \%$ & 456 & 0 & 0 & 14 & 17 & 33 & 0 & 0 & Lorenzo Martinez et al., 2014 \\
\hline RdM-XI & Roc de Marsal & XI & $63.5 \%$ & 524 & 7 & 0 & 2 & 9 & 0 & 205 & 2 & Turq, 1992 \\
\hline RdM-X & Roc de Marsal & $\mathrm{X}$ & $52.4 \%$ & 521 & 4 & 0 & - & 10 & 0 & 188 & 0 & Turq, 1992 \\
\hline RdM-IX & Roc de Marsal & IX & $43.8 \%$ & 641 & 7 & 0 & 2 & 11 & 0 & 181 & 0 & Turq, 1992 \\
\hline VC & Vieux Coutet & 3 & $18.4 \%$ & 804 & 155 & 17 & 26 & 126 & 6 & 0 & 2 & Bourguignon et al., 2004a,b \\
\hline
\end{tabular}

$\mathrm{Nb}$ : number; ${ }^{1}$ retouched tools; ${ }^{2}$ assemblage size; ${ }^{3}$ Levallois flake; ${ }^{4}$ Levallois core; ${ }^{5}$ pseudo-Levallois point; ${ }^{6}$ éclat débordant; ${ }^{7}$ Discoidal core; ${ }^{8}$ Quina-type flake; ${ }^{9}$ nonLevallois laminar production (including blades, blade cores and by-products).

The seventh category comprises products associated with nonLevallois blade production systems (Fig. 5). Mousterian blade technologies are now well recognized and widely documented in Europe, especially northern France and Belgium (e.g. Boëda, 1988; Conard, 1992; Otte, 1994; Revillion, 1995; Delagnes, 2000; Kuhn and Bietti, 2000; Kozlovsky, 2001; Depaepe, 2002), where these assemblages are particularly well represented in MIS 5. These types of flaking systems, while considerably less frequent in south-western France, have nevertheless been documented from contexts spanning MIS $5 \mathrm{~b}$ to 3 (Soressi, 2002; Blaser et al., 2012; Faivre, 2012; Ortega et al., 2013). Our sample includes prismatic or semi-prismatic cores as well as laminar removals clearly distinct from Levallois products given their elongation, robustness and trapezoidal or triangular cross-sections. Elements related to the maintenance of the debitage surface and volume (e.g. neo-crests, corticallybacked blades) were also counted.

All of these categories correspond to products of particular, welldocumented flaking methods. We have, however, intentionally excluded bifacial tools and evidence for their production in the analysis for several reasons. First, bifacial shaping is seldom exclusively represented in any assemblages and, those that do have a heavy bifacial component (bifaces and/or evidence for their manufacture) come from old excavations (e.g. La Ferrassie, Pech de L'Aze I, Le Moustier, Abri Peyrony) suffering clear collector bias and lacking systematic sieving. Second, site function issues, the high spatio-temporal fragmentation of bifacial shaping (Geneste, 1985; Turq, 2000; Soressi, 2002; Turq et al., 2013; Brenet et al., 2016; Deschamps, in press) in combination with the high potential of resharpening of bifacial tools (Boëda et al., 1990, 1991; Bourguignon, 2001) as well as the elevated mobility of bifaces presently makes discerning the importance of bifacial shaping in any given assemblage difficult. For example, while no bifaces and a handful of bifacial thinning flakes were recovered from layer K of Les Fieux (Faivre, 2006) the opposite is true for La Plane (Turq, 2000).
Finally, our database of recently excavated and critically reassessed assemblages shows nearly half (n 19) to be associated with one or several of the dominant flake production systems (Table 1). Before bifacial shaping can be integrated in any discussion of the structure of Mousterian variability considerable work needs to be done, including new modern excavations, which fortunately is the case for several of the sites mentioned above, alongside a systematic revision of small finds from recent field projects in order to identify typical by-products associated with biface manufacture and maintenance (e.g. Gravina, in press).

\section{Results}

Table 2 presents raw counts of technologically diagnostic ele- ments for each assemblage. Correspondence analysis demonstrates three factors to explain $91.4 \%$ of the variability in our dataset (Fig. 6). Factor 1 distinguishes assemblages principally according to the abundance of Quina-type flakes. Factor 2 separates assemblages richer in pseudoLevallois points, éclats débordants and Discoid cores (these 3 variables being highly correlated) from assemblages with a heavy Levallois (flakes and cores) and non-Levallois blade component. Factor 3 individualises assemblages with more evidence of non-Levallois blade production.

Plotting the assemblages along these 3 factors (Fig. 6) reveals a strong clustering of assemblages in at least 3 distinct groups. These three groups gather assemblages that were previously described as being dominated by Quina, Discoid or Levallois CO. In no case does an assemblage previously identified with one dominant $\mathrm{CO}$ appear in a cluster correlated with any of the other two. The first group is the most distinctive in that it contains assemblages where the Quina $\mathrm{CO}$ is exclusive. In the second group, assemblages exclusively associated with the chordal Discoid CO are highly clustered together and separated from other assemblages; while the more "mixed" assemblages of Combe- Grenal level 12 (chordal Discoid Levallois laminar) and the quartz component from Les Fieux level K (Centripetal Discoid bipolar anvil) are closer to the other groups. 

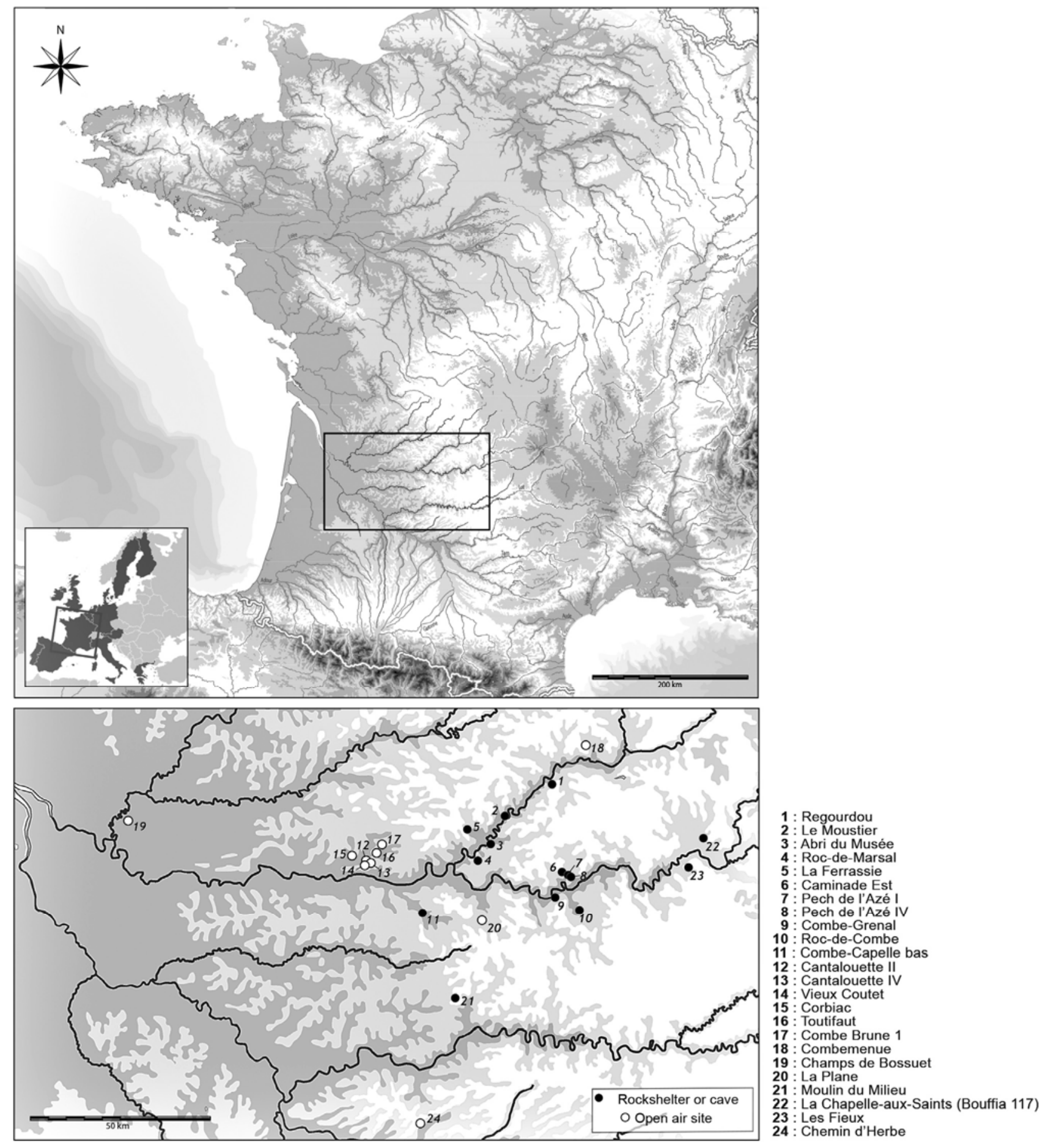

Fig. 1. Study area and Middle Palaeolithic sites included in the analysis.

Assemblages from the third group, dominated by Levallois $\mathrm{CO}$ (green and blue circles (in the web version) on Fig. 6), can be partially separated from each other on the third axis, with two assemblages (Cantalouette 1 and Combe-Grenal level 29-30) richer in nonLevallois blade products. The comparison of retouched tools proportions with flake pro- duction systems, as well as their exclusive or coexisting character, highlights several notable differences (Fig. 7). The Quina assemblages from Roc-de-Marsal are distinguished by a higher percentage of retouched tools than in all the other assemblages
As noted elsewhere (Faivre et al., 2013; Gravina and Discamps, 2015), assemblages in which the chordal Discoid method is exclusive or dominant contain less than $10 \%$ retouched tools. The same is true for Les Fieux (level K), where the use of metaquartzites likely conditioned flaking choices (bipolar on anvil and centripetal Discoid), the low rate of retouched tools (in most cases less than $5 \%$ of the entire series) being closely correlated to chordal Discoid flaking method. Assemblages dominated by Levallois CO have more variable percentages of retouched tools, but remain low when the Levallois method is exclusive. 

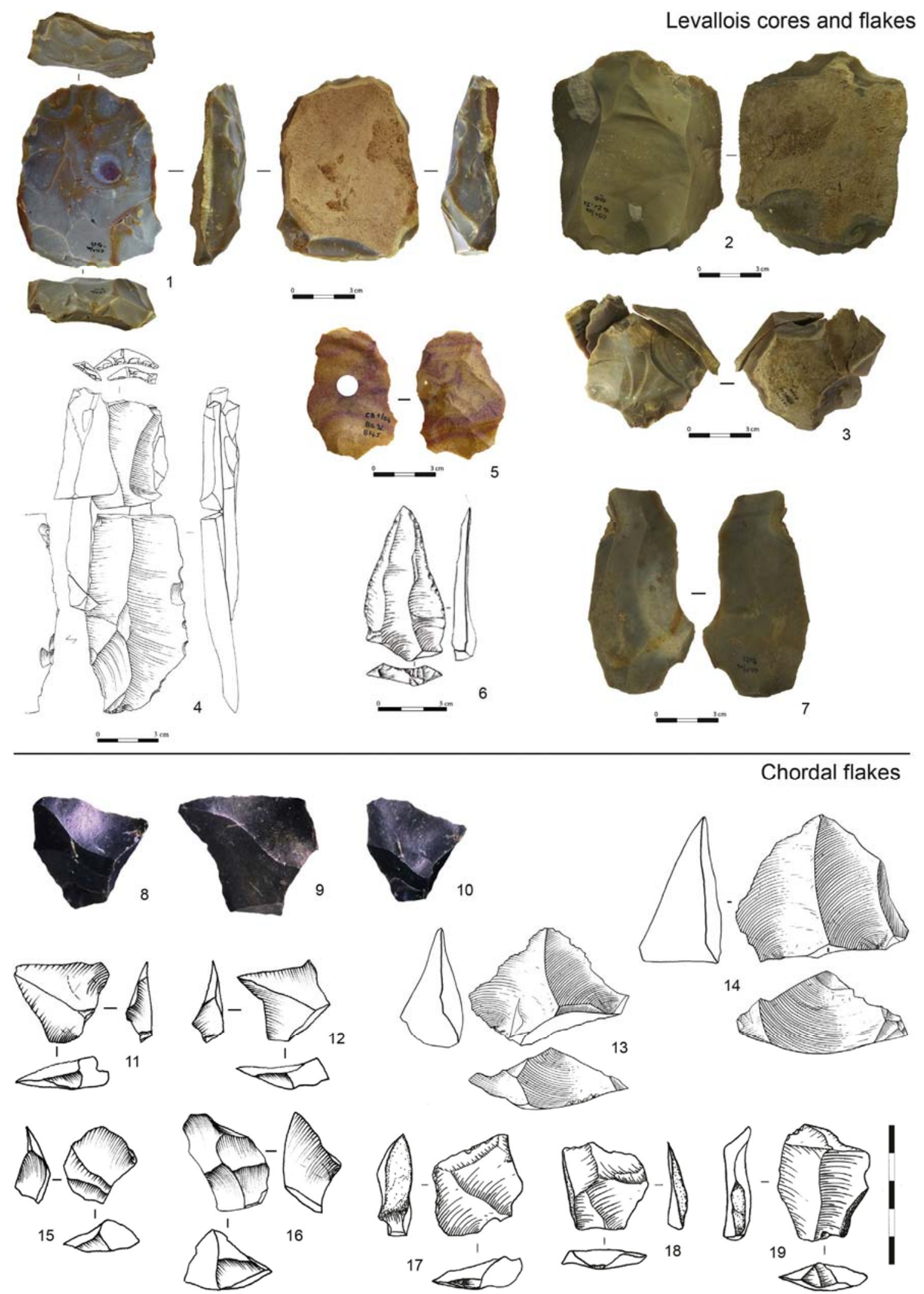

Fig. 2. Levallois cores $\left(\mathrm{n}^{\circ} 1 \mathrm{e} 3\right)$ and products $\left(\mathrm{n}^{\circ} 4 \mathrm{e} 7\right)$. Pseudo-Levallois points ( $\mathrm{n}^{\circ}$ 8e 14$)$ and éclats débordants $\left(\mathrm{n}^{\circ} 15 \mathrm{e} 19\right)$. Illustrations $\mathrm{n}^{\circ} 13$ and 14 (Le Moustier) by G. Devilder. 

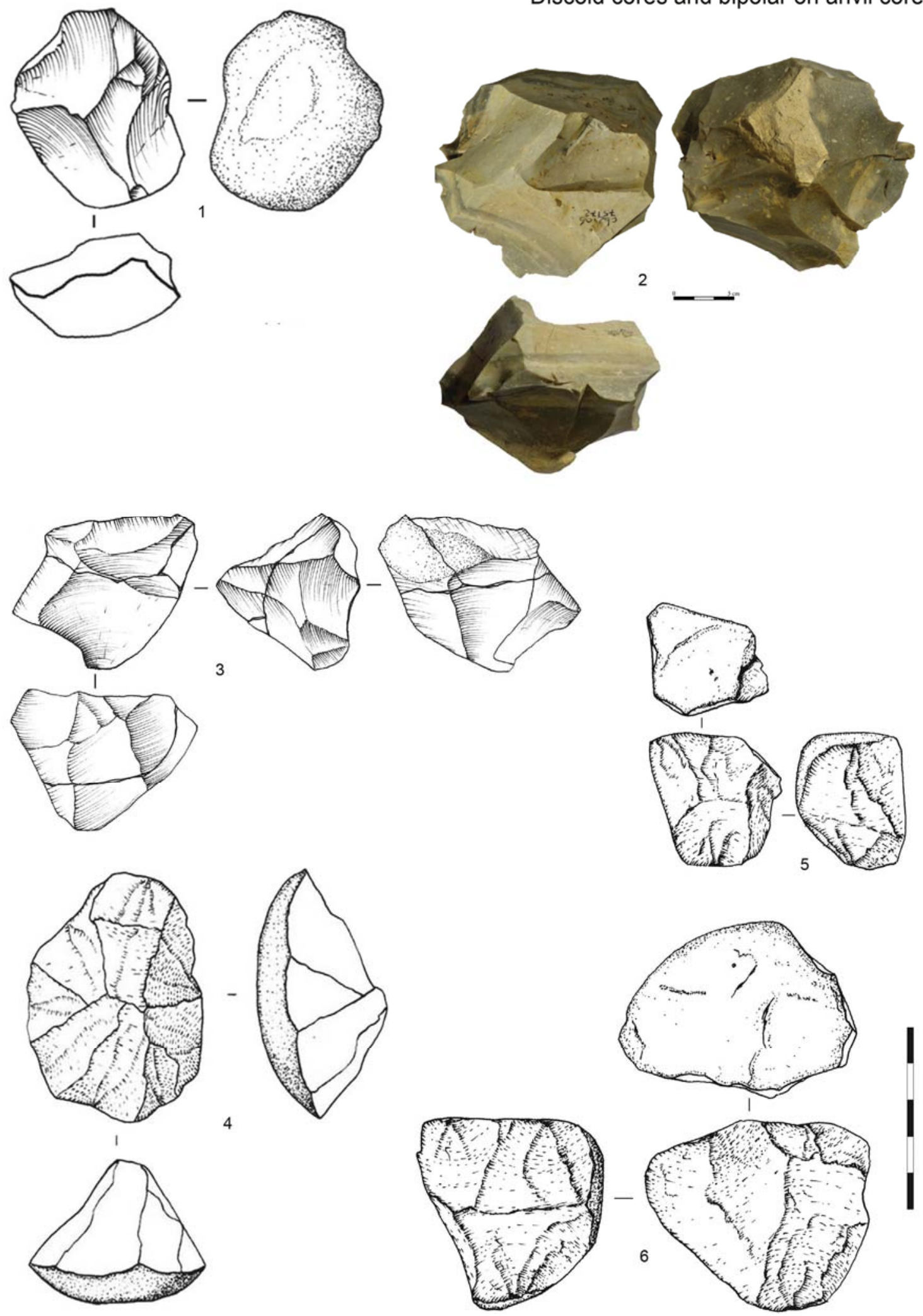

Fig. 3. Discoid cores. Unifacial e flint $\left(n^{\circ} 1\right)$, unifacial e metaquartzite $\left(n^{\circ} 4\right)$, bifacial e flint $\left(n^{\circ} 2,3\right)$. Bipolar debitage on metaquartzite $\left(n^{\circ} 5,6\right)$.

\section{Discussion}

The nature of any lithic assemblage is, by necessity, structured by different elements, including natural processes such as sedimentation rates. Cultural factors (choices) determine artefact use and discard as well as the form in which artefacts are ultimately incorporated into the archaeological record, each resulting from a specific phase in the reduction of a volume of raw material. 


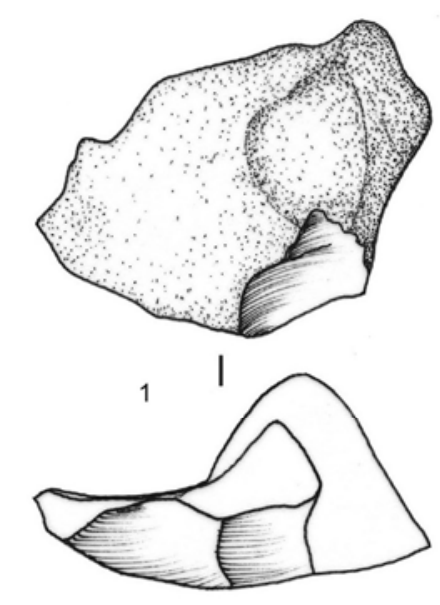

\section{Quina-type flakes}
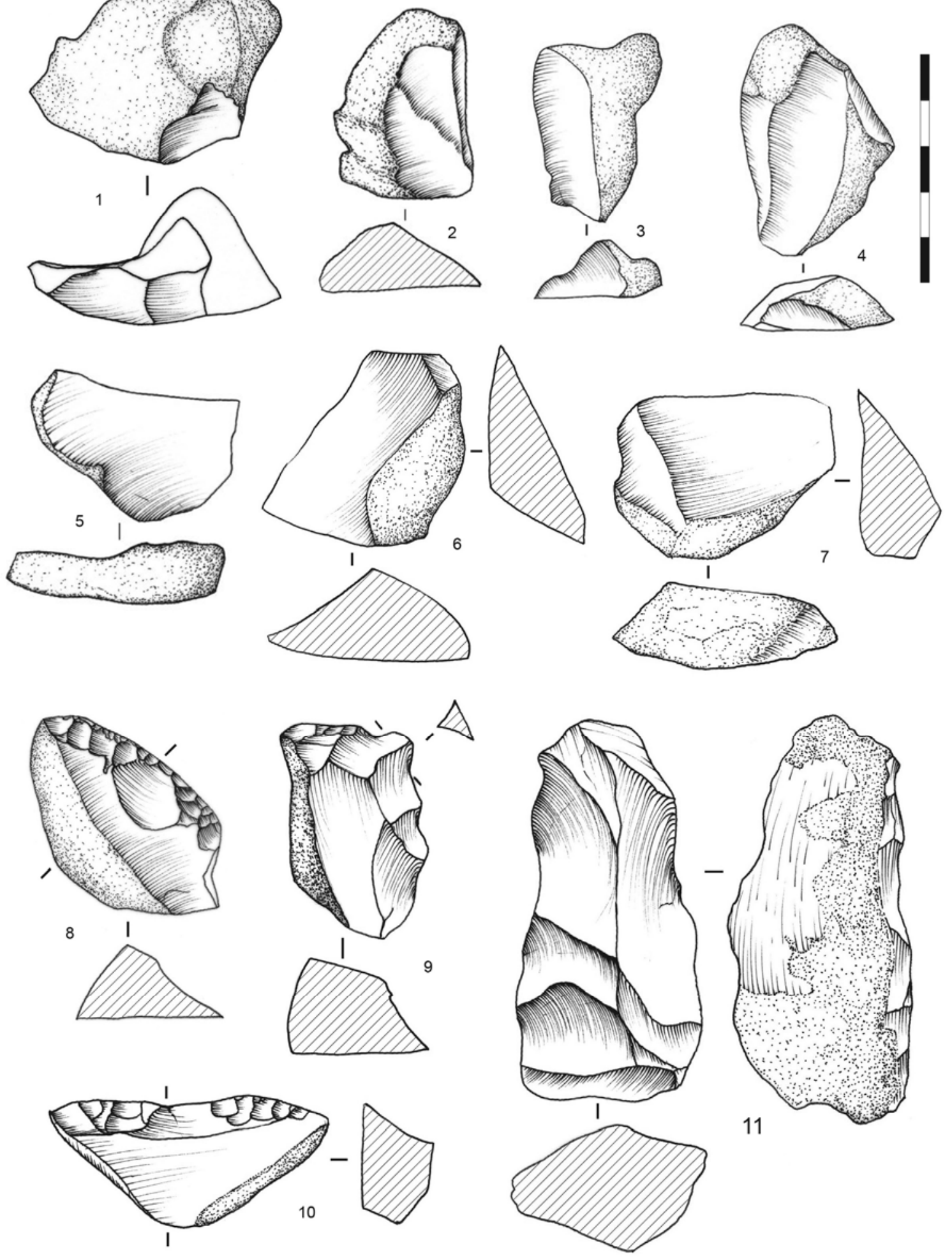

Fig. 4. Quina-type flakes.

Experimental data collected over the last 20 years and commonly employed in $\mathrm{CO}$ analysis permits many but certainly not all diagnostic objects to be reliably placed in a specific stage of the reduction sequence (e.g. Geneste, 1988; Turq, 1990; Brenet et al., 2009, 2011, 2013; Roussel et al., 2009; Bourguignon et al., 2011a, 2013; Ortega et al., 2013).
Moreover, progress in raw material sourcing and the tracing of their postgenetic alteration (Fernandes, 2012) allow aspects of artefact mobility and the segmentation of the CO to be better understood (Turq et al., 2013). What emerged from these works was not, as misunderstood by 

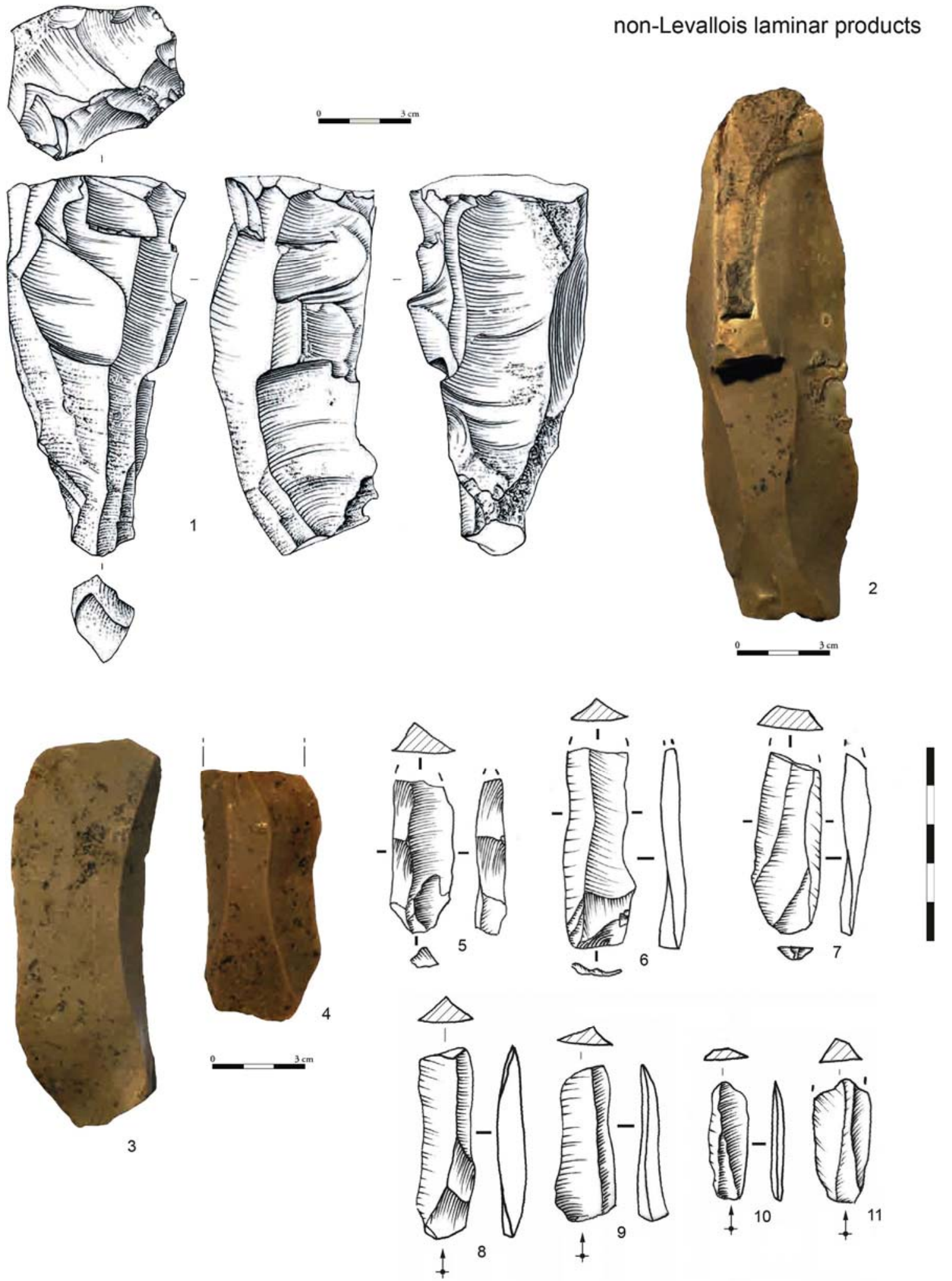

Fig. 5. Non-levallois blade cores and products.

Monnier and Missal (2014:61), a "severe blow to the notion that the CO approach enables us to reconstruct the intentions of prehistoric knappers", but simply that other artefact forms (e.g. large cortical and non-cortical flakes, cores, etc.) in addition to identifiable end-products are also moved around the landscape (see also Turq et al., in press), reflecting more complex economic choices than previously thought.

The identification of any specific reduction sequence, for example Levallois or Discoid, should never be determined solely on the presence of a single object. 

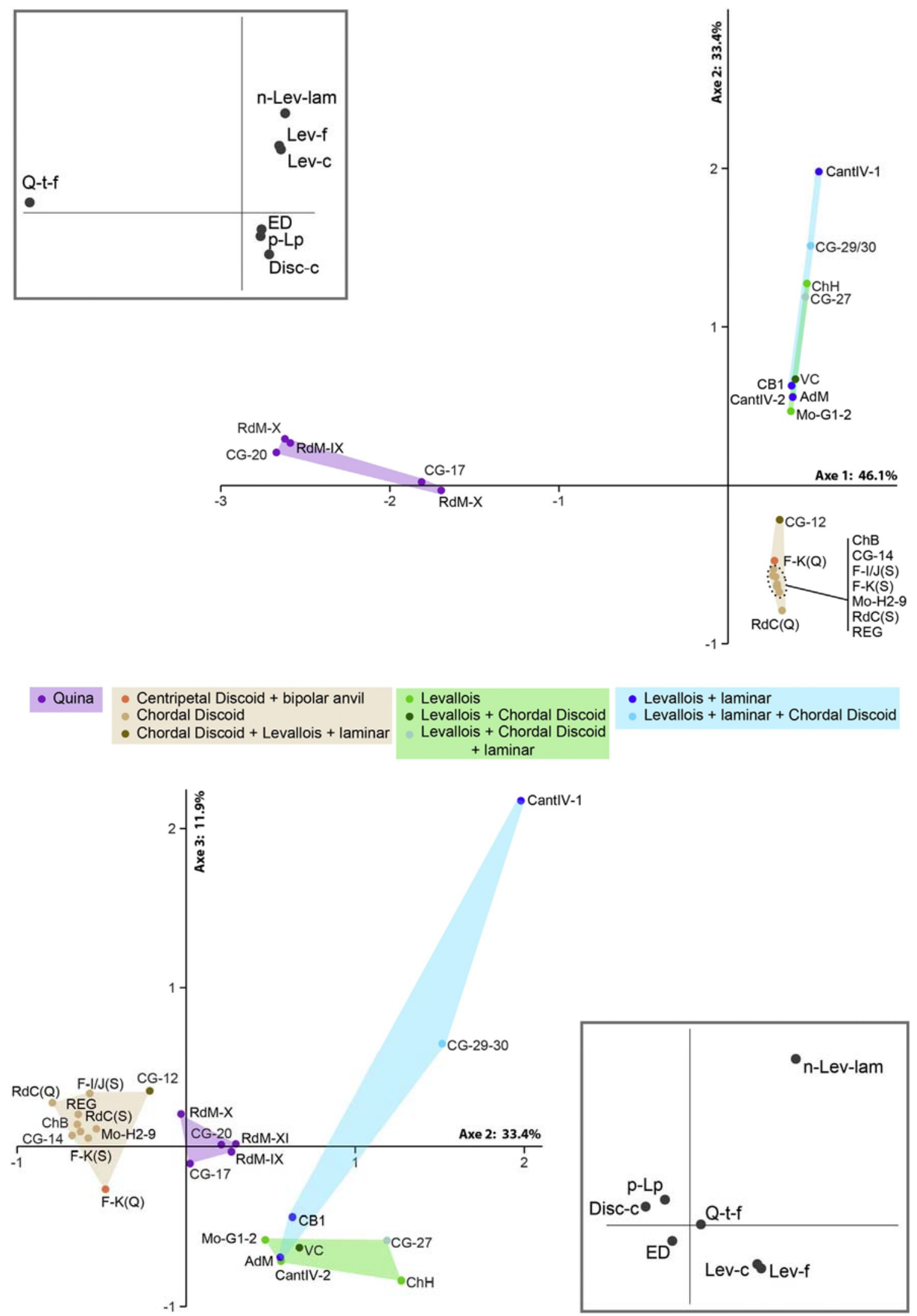

Fig. 6. Correspondence analysis. For site codes see Table 2.

The presence of éclats débordants is not necessarily synonymous with Levallois or Discoid debitage, it is, rather, the conjunction of typical products and by-products with specific technical criteria determined by experimentation and refitting that allows the production methods underlying the formation of an assemblage to be determined.
In the same sense, assemblage type should never be determined solely with recourse to core type or form. 


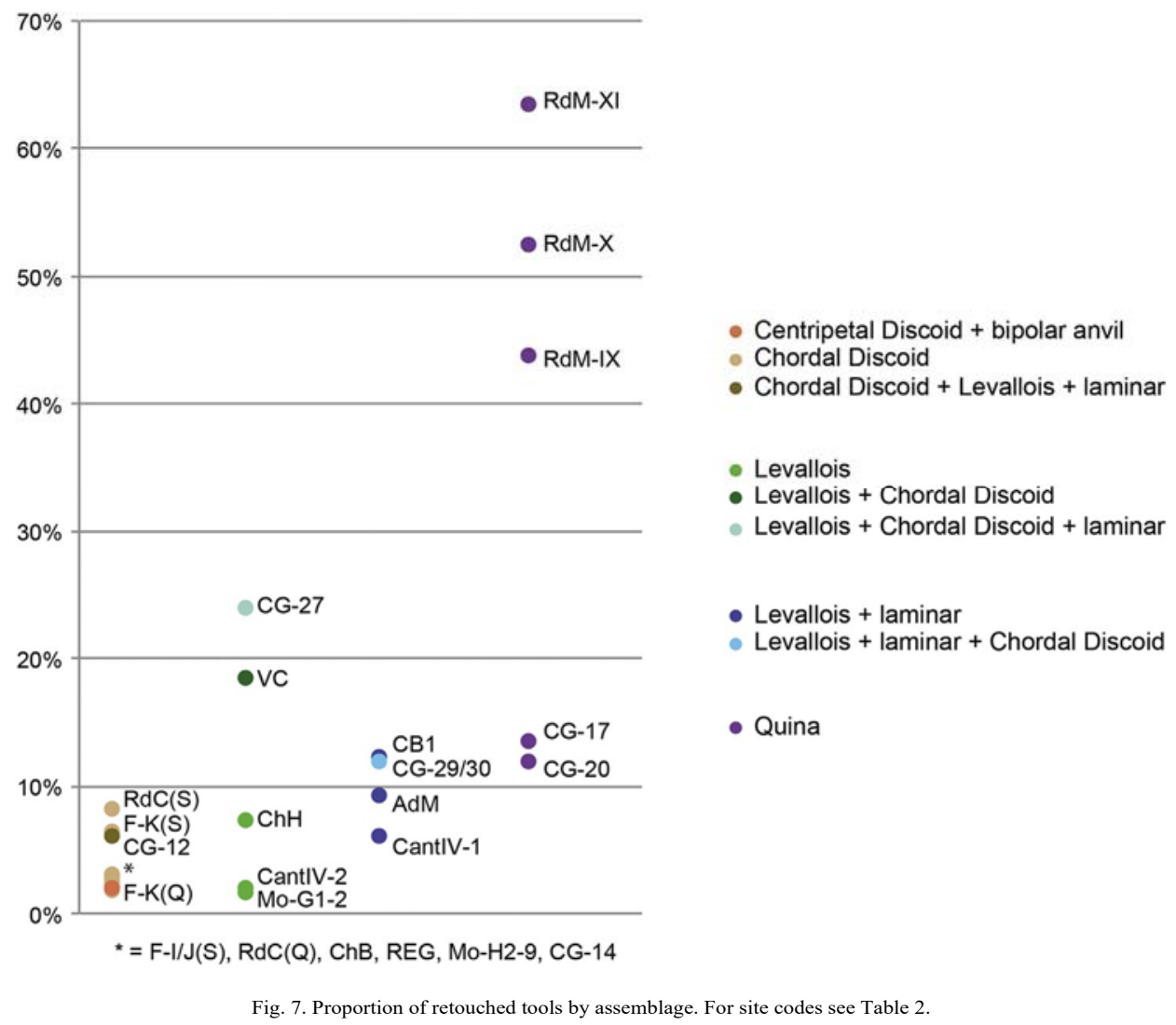

For example, while 30 years ago the problems originally noted by Lenoir and Turq (1995) and repeated by Monnier and Missal (2014) did exist in terms of distinguishing Discoid from Levallois debitage, they have, in no small part, been resolved by refitting studies, numerous technological analyses and experimentation (e.g. articles in Peresani, 2003).

\section{On the identification and definition of technocomplexes}

Correspondence analysis confirms that a quantitative technological approach is possible, and that the commonly employed groups (Quina, Discoid, Levallois) pertain to genuine differences in the relative representation of technologically diagnostic elements in lithic assemblages. Moreover, the artifact counts treated in the correspondence analysis were produced by different analysts (Table 2), reinforcing the reproducibility of a technological approach to Middle Palaeolithic lithic assemblages.

The proportions of these diagnostic technological elements can serve as the structural framework for better defining lithic technocomplexes (LTC). Middle Palaeolithic LTC were initially defined as the material expression of the practical know-how evident in lithic reduction sequences (or chaine opératoire), which is shared across a range of human groups (Delagnes et al., 2007). Defined as such, this concept was subsequently used to restructure Mousterian variability and revisit the archeo-sequences from southwestern France (Jaubert et al., 2011; Jaubert, 2012). This revision, while not completely departing from certain of Bordes' facies, provided a new vision of the chronological patterning of Mousterian assemblage types in the region. Monnier and Missal (2014:63) took exception to this new synthesis, while at the same time clearly recognizing the fact that Jaubert had underlined the preliminary nature of the synthesized Middle Palaeolithic archaeo-sequence for south-western France.

They note that (1) no data is presented to support the technocomplexes, (2) it is unlikely that different researchers would attribute the same assemblage to the same LTC, and (3) that these LTC are not explicitly defined. We have already addressed the first two criticisms above.

Investigating industrial variability via coarse-grained patterns in median Levallois or biface indices, relative proportions of Levallois versus nonLevallois assemblages, retouched tool frequencies with the basic chronological unit being Marine Isotope Stage, as Monnier and Missal have done (Monnier, 2006; Monnier and Missal, 2014) appears inadequate, particularly given both the increasing recognition of rapid technological change within MIS 3 alone and the current resolution of absolute dating methods for the periods in question (e.g. Discamps et al., 2011; Jaubert et al., 2011; Faivre et al., 2014; Gravina and Discamps, 2015). The key element for both defining LTC and addressing aspects of Neanderthal techno-economic behavior should remain lithic production systems, which can be exclusive or coexist within assemblages. Several decades of research, experimentation and refitting, within a $\mathrm{CO}$ framework or otherwise, have resulted in a series of clearly identifiable and quantifiable elements (i.e. the technological groups used in the correspondence analysis, see above) that distinguish each system. Based on the above, at least three main techno- complexes can be identified in our study region.

\subsection{Levallois system LTC}

In the LTC based on the Levallois system (Boëda, 1986, 1994, 2013; Geneste, 1988; Boëda et al., 1990), the organisation of core reduction sequence plays a central role (Fig. 8). The Levallois system (Boëda, 1986, 1994; Geneste, 1988; Boëda et al., 1990) produces standardized blanks with a high degree of predetermination (Lycett and Eren, 2013). The productivity of the method can vary, ranging from a single preferential flake to multiple production episodes 

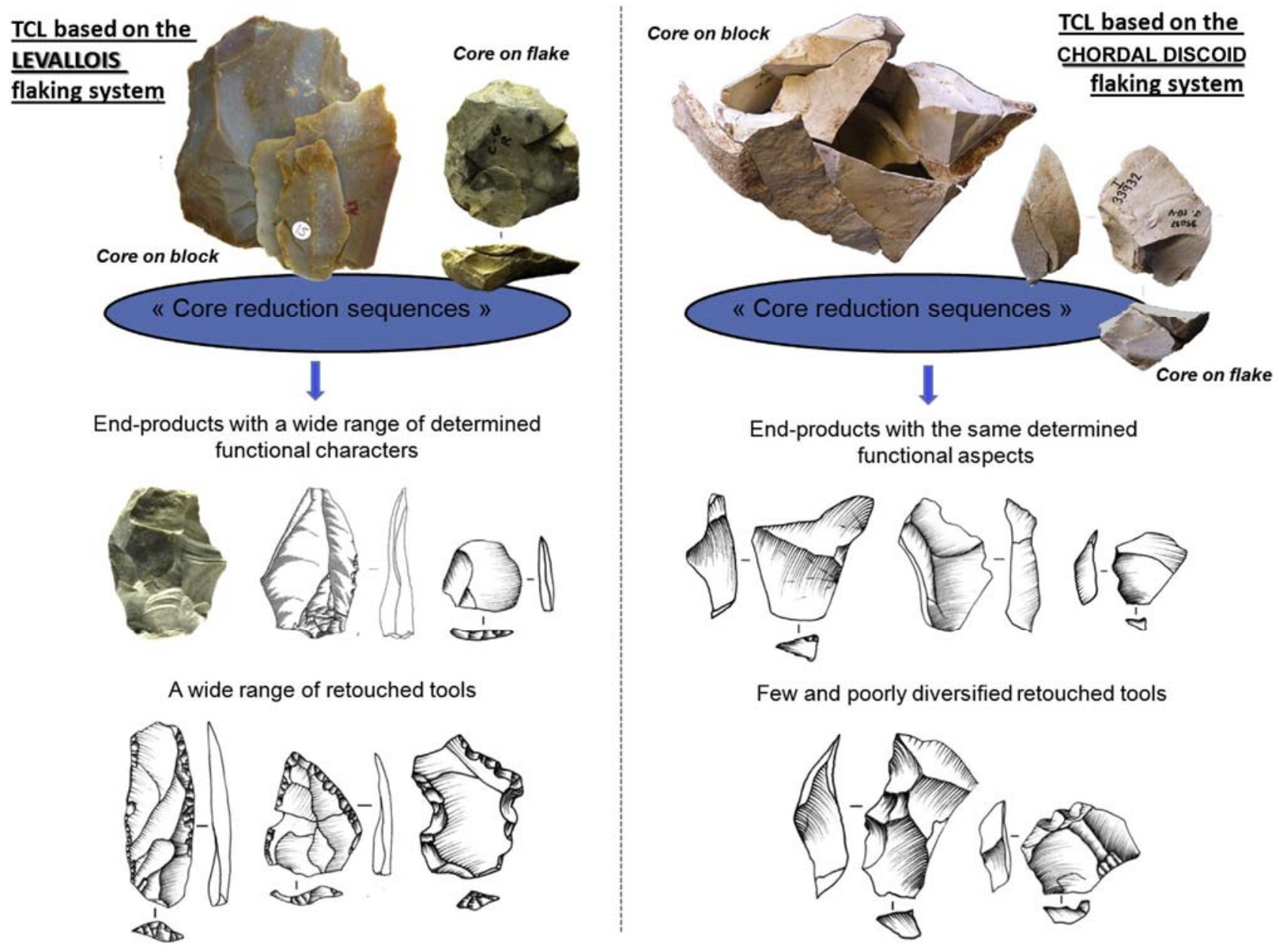

End-products with the same determined functional aspects
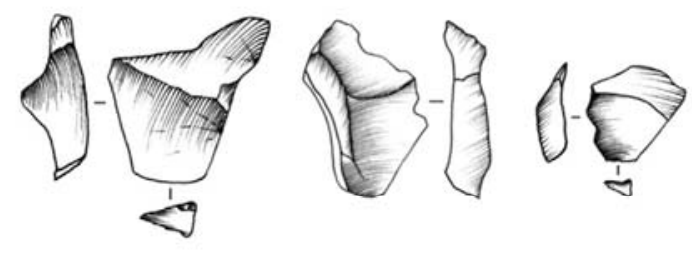

Few and poorly diversified retouched tools

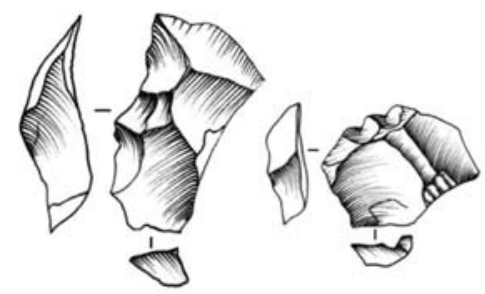

Fig. 8. Organisation of Levallois and Discoid LTC.

(Bourguignon et al., 2006), following the reinstallation of the core volume and the removal of specific convexity management flakes (Boëda's 2013, Type E). Levallois products present a wide range of functional features, either when unmodified or following resharpening or reduction trajectories of different intensities resulting in various scraper and denticulate tool forms (Dibble, 1984, 1987, 1995). This large variety of tool types, the foundation of Bordes' facies, is a component of the Levallois techno-complex not a defining feature. The fact that unmodified Levallois products are readily functional likely explains the low number of retouched tools in several assemblages (Fig. 7). Moreover, the exportation of both large Levallois and other types of flakes from certain sites, as demonstrated by a technological analysis and refitting of the open-air assemblage from Cantalouette 2 (Bourguignon et al., 2008), probably also influences the proportion of retouched Levallois products.

\subsection{Discoid system LTC}

The LTC based around the Discoid system (Boëda, 1993; Mourre and Jaubert, 1993; Peresani, 2003) are marked by flaking modalities (one, two or several flaking surfaces) whose particular configuration produces a series of predetermining and predetermined flakes (Fig. 8). However, the initial configuration stage is less complex (Bourguignon et al., 2006); flaking surfaces are unprepared and require no specific maintenance flakes (Type D volume; Boëda, 2013). Removals are essentially oriented around the continual maintenance of suitable flaking angles between flaking surfaces and striking platforms, with the creation of ridges (guides) as the main predetermining criteria. In the study region, the chordal Discoid method (see above) is geared around the recurrent production of flakes with the same morpho-technical features along the same technological axis (oblique) of the core (Boëda, 1993). This highly productive flaking system is primarily connected to the production of "pseudo-Levallois points" and éclats débordants. The identification of a ramified Discoid reduction sequence involving flakes, often thick cortical elements, used as cores introduces variability in the sizes of these two main production objectives (Turq and Bourguignon, 2003; Bourguignon et al., 2004; Faivre, 2008; Gravina and Discamps, 2015).

This system appears organised around the production of identical or highly similar removals, and finds some similarities with Levallois systems. Both are flake production methods, varying in complexity depending on the operational stage, whose objective is the production of standardized flakes in terms of form. The functionally predetermined nature of Levallois products is equally evident in those produced by the Discoid flaking system, as can be seen in the low retouch frequencies for most Discoid assemblages in the northeastern Aquitaine Basin. Typical Discoid products (i.e. pseudoLevallois points and éclats débordants), with their predetermined functional properties, an active edge opposite a "back", were probably used unretouched, as supported by several use- wear analyses (Bourguignon et al., 2000; Lemorini et al., 2003; Rios-Garaizar, 2007). These types of assemblages have also been associated 
with specific site types geared around butchery activities (Brugal, 1999; Locht, 2003; Martinez et al., 2003; Coumont, 2005; Brugal et al., 2013).

If the chordal modality is best represented in the studied as- semblages, the centripetal Discoid modality appears uniquely in association with the use of metaquartzites, which are the main raw materials available in certain geographical areas (e.g. Quercy region). Several technological studies have shown that this modality, often associated with bipolar flaking on anvil, could be a response to raw material contraints, with the natural convex surface of quartz pebble serving as effective striking platforms (Jaubert and Mourre, 1996; Thiébaut et al., 2008; Faivre et al., 2013). These modalities produce secant centripetal flakes with wide, thick cortical platforms opposite two convergent edges. Whatever the flaking modality (chordal on flint or centripetal on quartz), end- products seem to share the same morphotechnical features (Faivre, 2004).

\subsection{Quina system LTC}

The Quina system (Turq, 1989; Bourguignon, 1996, 1997; Faivre, 2008, 2011) is structured around a combination of operational stages that are no less complex than either the Levallois or Discoid systems. Central to the Quina flaking methods is the production of a wide range of predetermining and predetermined flakes which are integrated into various functional and production objectives (Fig. 9). Importantly, the Quina system is not limited to strictly functional objectives represented by a specific tool group side-scrapers with Quina or demi-Quina retouch. Quina debitage is organised around the production of asymmetrical flakes (in section or profile) with at least one elongated edge opposite a thick face (lateral back or platform) (Turq, 1989; Bourguignon, 1996, 1997; Faivre, $2008,2011)$. These products, although varying in size over the course of the reduction sequence, nevertheless remain essentially identical and afford diverse and complementary morpho-functional possibilities (Bourguignon et al., 2006). Moreover, the volumetric potential of Quina-type flakes, particularly in terms of their thickness, allows different core-on-flake/tool (the éclat matrice in French; Bourguignon et al., 2004; Faivre, 2011) reduction sequences. This represents an important departure from the standardised products typical of the Levallois and Discoid systems to the extent that technical investment is not primarily focused on the 'core'.

\section{Mixed system LTC}

A number of assemblages ( $\mathrm{n}=11$, Table 2$)$ provide evidence for the combination of two or more systems described above. It is important to note that in all of these mixed LTC, one system is clearly dominant (the first listed in Table 2). It is interesting to note that the Quina is the only system never found in association with another one. Levallois and non-Levallois blade systems are found together in 3 instances, 5 cases combine the chordal Discoid and Levallois systems with evidence for non-Levallois blade production, with the final 3 described as a mix of Levallois with the production of unipolar elongated flakes (see below). In some cases, these mixed assemblages may be interpreted as local adaptations to raw material constraints, where imported elements (non-local raw materials) of one system are found alongside those of another produced on-site in, what are often, poor quality raw materials (Chalard et al., 2007; Faivre et al., 2013).

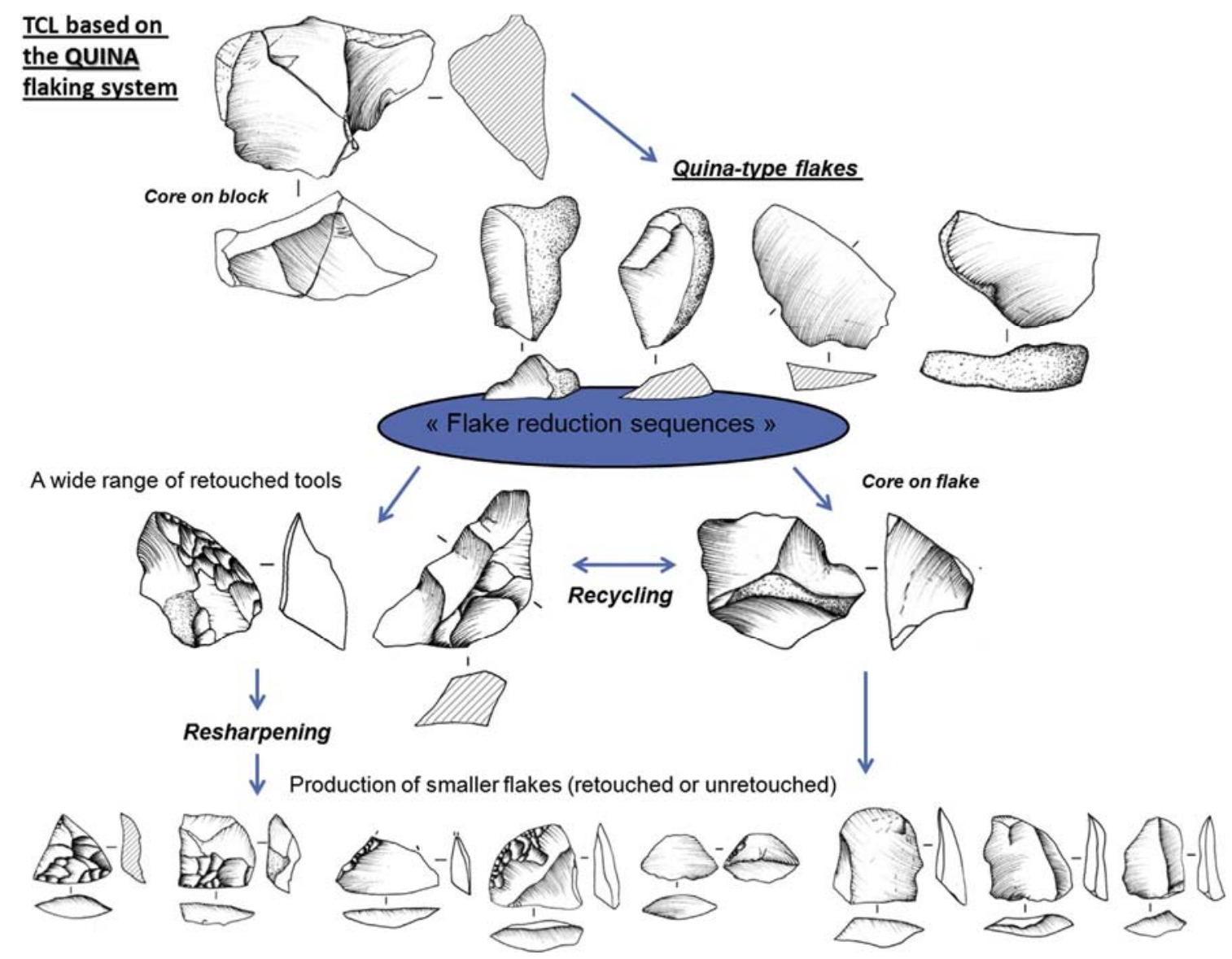

Fig. 9. Organisation of the Quina LTC. 


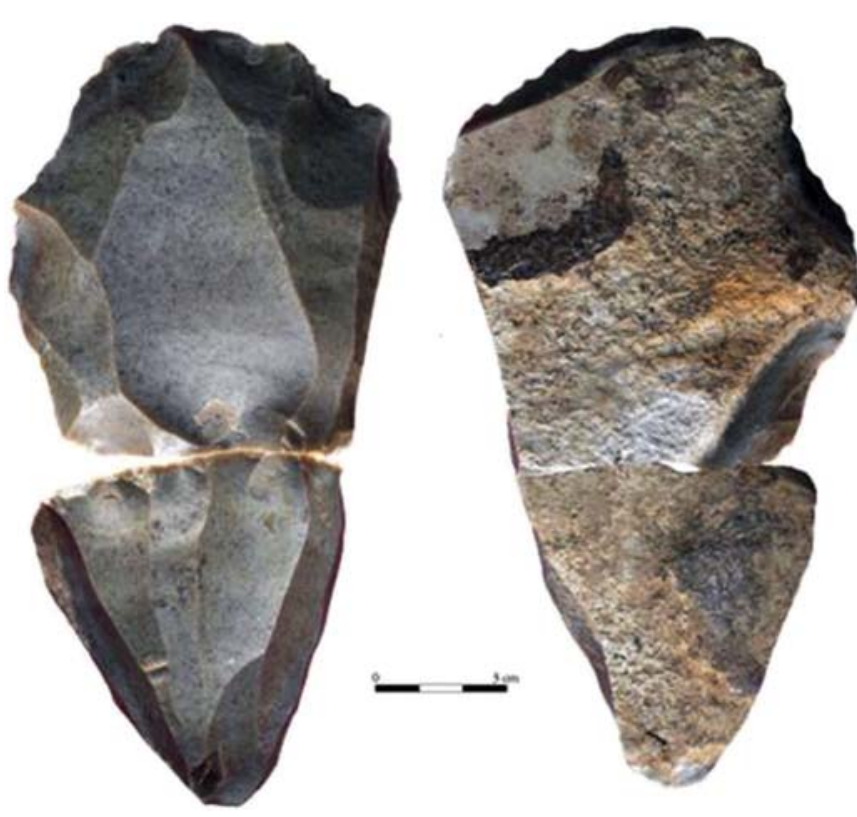

Fig. 10. Refit between a Levallois core and a non-Levallois blade core from Cantalou- ette IV (Blaser et al., 2012).

More often than not, mixed assemblages concern the same local raw material, rendering it difficult, if not impossible, to distinguish imported elements. Here, the combination of different systems could be interpreted as reflecting disturbances between different non-synchronous assemblages, especially in cave or rock shelter sequences. However, spatial data and refits at open-air sites succinctly demonstrate the coexistence of Levallois and non-Levallois blade production within the same occupation, as at Cantalouette IV (Blaser et al., 2012; Fig. 10). Additionally, several open-air assemblages show the combination of Levallois and chordal Discoid systems in the same knapping areas or, as revealed by refits, between adjacent areas (Brenet, 2012).

\section{Conclusion}

Lithic technology, like any other research field, is based on concepts and terminology shared by an international community of researchers who worked and are still working on the contexts discussed in this paper. Here we have shown that, based on well- defined technological criteria (i.e. an explicit typology), the chaîne opératoire approach can rely on quantitative data. Statistical analysis of this quantitative technological data supports previous qualitative $\mathrm{CO}$ descriptions. The identification of a specific $\mathrm{CO}$ in a given lithic assemblage is thus neither ad hoc nor intuitive, but rather a reliable methodological tool supportable by quantitative data. Certain LTC can be defined both qualitatively and quantitatively and serve as the most secure basis for advancing our un- derstanding of Mousterian techno-economic variability. Similar approaches combining quantitative data and chaîne opératoire derived observations have also been successively employed to either identify reduction stages (Scerri et al., 2015) or incorporate technological analysis with raw material economy (Will et al., 2014). Despite the fact that the combination of different analytical approaches is more often than not beneficial, the advantages of including technological data in lithic studies are, in our opinion, evident. The chaîne opératoire approach elaborated here not only succeeded in identifying clear patterns of shared technological behaviour but also infuses models of Neandertal techno- economy, mobility patterns, and landscape exploitation with a dynamism that strictly quantitative approaches are, in our opinion, likely to fail to detect.

The LTC identified here group distinct assemblages that share a common, recurrent and, more often than not, exclusive flake production system. The technological definition of LTC succinctly moves us beyond both the dependence on retouched tool types and the dichotomy of Levallois and non-Levallois assemblages, leading to the ultimate abandonment of the culturally charged 'facies' concept of Bordes. The preliminary adoption of the more neutral term 'techno-complex' embodies shared technological behaviours that structure Mousterian industrial variability. Currently, the search for their 'meaning', however, appears pre- mature, confounded by the lack of faunal data, raw material exploitation patterns, and comparable chronological information for many of the assemblages considered here.

\section{Acknowledgements}

The authors would like to thank the Service regional d'archeologie (Nathalie Fourment) and the Musée national de Préhistoire, especially its director J.-J. Cleyet-Merle, as well as Peggy Jacquement, Stephane Madelaine, Bernard Nicolas. We are also grateful to all the participants of the USIPP B40 e Cleaning up a messy Mousterian: how to describe and interpret Late Middle Palaeolithic chrono-cultural variability in Atlantic Europe (Burgos, September 2014). We would also like to thank G. Devilder for the Le Moustier artefact illustrations. This research forms part of the NéMo project financed by a grant from the French National Research Agency program Investissements d'avenir (ANR-10-LABX-52), and BG would like to recognise the French Ministry of Culture and Communication (MCC) for an Allocation de Recherche et Formation that helped fund part of this research. We are grateful to Wil Roebroeks and Manuel Will for constructive comments that helped to improve the manuscript.

\section{References}

Bar-Yosef, O., Van Peer, P., 2009. The chaîne opératoire approach in Middle Paleolithic archaeology. Current Anthropology 50 (1), 103-131.

Binford, L.R., Binford, S.R., 1966. A preliminary analysis of functional variability in the Mousterian of Levallois facies. American Anthropologist 238-295.

Blaser, F., Bourguignon, L., Sellami, F., Rios Garaizar, J, 2012. Une série lithique à composante Laminaire dans le Paleolithique moyen du Sud-Ouest de la France: le site de Cantalouette 4 (Creysse, Dordogne, France). Bulletin de la Société préhistorique française 109(1), 5-33.

Bleed, P., 2001. Trees or chains, links or branches: conceptual alternatives for consideration of stone tool production and other sequential activities. Journal of Archaeological Method and Theory $8(1), 101-127$.

Boëda, E., 1986. Approche technologique du concept Levallois et évaluation de son champ d'application: étude de trois gisement saaliens et weichseliens de la France septentrionale (Doctoral dissertation, Paris 10).

Boëda, E., 1988. Le concept laminaire: rupture et filiation avec le concept Levallois. In: Otte, M. (Ed.), L'Homme de Néandertal. Actes du colloque international de Liège (4e7 décembre 1986), vol. 4, La mutation. Kozlowski, J.K. (Coord.), Liège: Service de préhistoire, Université de Liège, 1988, ERAUL 35, pp. 41-60, ill.

Boëda, E., 1993. Le débitage discoïde et le débitage Levallois récurrent centripète. Bulletin de la Société préhistorique française 90 (6), 392-404.

Boëda, E., 1994. Le concept Levallois: variabilité des méthodes. CNRS éd.

Boëda, E., 2013. Techno-logique \& Technologie. Une paléo-histoire des objets lithiques tranchants. @rchéo-éditions.

Boëda, E., Geneste, J.M., Meignen, L., 1990. Identification de chaînes opératoires lithiques du Paléolithique ancien et moyen. Paléo 2 (1), 43-80.

Bordes, F., 1961. Typologie du Paléolithique inférieur et moyen. Bordeaux: Delmas, 1961. In: Mémoire 1, 2 vol.. Publications de l'Institut de Préhistoire de l'Université de Bordeaux.

Bourguignon, L., 1996. La conception de débitage Quina. In: Bietti, A., Grimaldi, S. (Eds.), Reduction Processes for the European Mousterian. Actes du colloque international de Rome, Quaternaria Nova, VI, pp. 149-166.

Bourguignon, L., 1997. Le Moustérien de type Quina: nouvelles définitions d'une entité technique (Doctoral dissertation, Paris 10). 
Bourguignon, L., 2001. Apports de l'expérimentation et de l'analyse techno- morphofonctionnelle à la reconnaissance du processus d'aménagement de la retouche Quina. In: Préhistoire et approche expérimentale, pp. 35-66.

Bourguignon, L., Morala, A., in press. Approche techno-économique de l'industrie lithique. In: Detrain, L., Bourguignon, L., Kervazo, B., Morala, A., Guadelli, J.-L. (Eds.), L'occupation moustérienne de l'Abri Musée (Les Eyzies de Tayac- Sireuil). Paléo Supplément. Musée National de Prehistoire, Les Eyzies.

Bordes, F., 1953. Essai de Classification des industries "moustériennes", Bulletin de la Sociéte préhistorique de France, pp. 457-466 (in press)

Bourguignon, L., Turq, A., 2003. Une chaîne opératoire de débitage sur éclat du Moustérien à denticulés aquitain: les exemples de Champs de Bossuet et de Combe-Grenal c.14. In Peresani, M. (Ed.), Discoïd Lithic Technology. Advances and Implications, BAR International Series, vol. 1120, pp. 131-152.

Bourguignon, L., Ortega, I., Brenet, M., Lenoble, A., Astruc, L., 2000. Le gisement moustérien de Champ de Bossuet. DFS, Afan, ASF et SRA Aquitaine, Bordeaux, p. 274.

Bourguignon, L., Ortega, I., Sellami, F., Brenet, M., Grigoletto, F., Vigier, S., Daussy, A., Deschamps, J.-F., Casagrande, F., 2004a. Les occupations paleolithiques découvertes sur la section Nord de la deviation de Bergerac: résultats préliminaires obtenus à l'issue des diagnostics. Bulletin Préhistoire du Sud- Ouest 11,155-172.

Bourguignon, L., Faivre, J.-Ph, Turq, A., 2004b. Ramification des chaînes opératoires: une spécificité du Moustérien. Paléo 16, 37-48.

Bourguignon, L., Delagnes, A., Meignen, L., 2006. In: Astruc, L., Bon, F., Léa, V. (Eds.), Systèmes de production lithique, gestion des outillages et territoires au Paléolithique moyen: où se
senten trouve la complexité, pp. 75-86.

Bourguignon, L., Blaser, F., Rios, J., Pradet, L., Sellami, F., Guibert, P., 2008. L'occupation moustérienne de la Doline de Cantalouette II: Spécificités technologiques et économiques premiers résultats d'une analyse intégrée. In: Jaubert, J., Bordes, J.-G., Ortega, I. (Eds.), Le sociétés du Paléolithique dans un grand Sud-ouest: nouveaux gisements, nouveaux résultats, nour

Bourguignon, L., Bidart, P., Turq, A., Rios, J., Ortega, I., 2011a. Etudes des vestiges lithiques. In Bidart, P., Bourguignon, L., Ortega, I., Sellami, F., Rios, J., Guibert, P., Turq, A. (Eds.), L Gisement Moustérien de Tradition Acheuléenne de Combe Brune 1, Déviation nord de Bergerac, Rapport Final d'Opération. Inrap, Paris, pp. 47-120.

Bourguignon, L., Brenet, M., Folgado, M., Ortega, I., 2011b. Aproximación tecno-económica de debitage Discoide de puntas pseudo-Levallois: El aporte de la experimentación. In: Morgado Rodríguez, A., Baena Preysler, J. (Eds.), La investigacion experimental aplicada a la arqueologia. Galindo, SL, Ronda, Malaga, pp. 53-59.

Bourguignon, L., Turq, A., Fauquignon, J., 2013. Lascas de puesta en funcionamiento, de reacondicionamiento y de reciclado de las raederas Quina: Estimación e interpretación tecno-económica. In: Experimentación en arqueología. Estudio y difusión. Sèrie Monográfica del MAC-Girona 25-1, Girona 2013, pp. 229-235.

Brantingham, P.J., Kuhn, S.L., 2001. Constraints on Levallois core technology: a mathematica model. Journal of Archaeological Science 28 (7), 747-761.

Brenet, M., 2012. Silex et roches métamorphiques au Paléolithique moyen. Com- bemenue et Chemin d'Herbe. In: Marchand, G., Querré G. (Dirs.), Roches et Sociétés de la Préhistoire entre Massifs cristallins et Bassins sédimentaires: le Nord-Ouest de la France dans son contexte européen, pp. 367-381.

Brenet, M., Bourguignon, L., Folgado, M., Ortega, I., 2009. Elaboration d'un protocole d'expérimentation lithique pour la compréhension des comportements techniques et d'experimentation lithique pour la comprehension des comportements techniques

renet, M., Bourguignon, L., Folgado, M., Ortega, I., 2011. Elaboración de un protocolo de experimentación lítica para la comprensión del comportamiento técnico y tecnoeconónico durante el Paleolitico medio. In: Morgado Rodriguez, A., Baena Preysler, J. (Eds.), La investigacion experimental a

Brenet, M., Bourguignon, L., Folgado, M., 2013. Approche expérimentale de la variabilité des industries du Paléolithique moyen. L'intérêt d'évaluer les niveaux de compétence et d'efficience des expérimentateurs. In: Experimentación en arqueología. Estudio y difusión. Sèrie Monográfica del MAC-Girona 25-1, Girona 2013, pp. 177-182.

Brenet, M., Chadelle, J.P., Claud, É, Colonge, D., Delagnes, A., Deschamps, M., Folgado, M., Gravina, B., Ihuel, E., 2016. The function and role of bifaces in the Late Middle Paleolithic of southwestern France: examples from the Charente and Dordogne to the Basque Country. Quaternary International 1-19. http:// dx.doi.org/10.1016/j.quaint.2015.12.052.

Brugal, J.-Ph., 1999. Etude de populations des grands bovidés européens: intérêt pour la connaissance des comportements humains au Paléolithique. In: Brugal, J.-Ph., David, F. Palé, Jithique aux paleoindiens des grandes plaines. Ed. APDCA, Antibes, pp. 85-104.

Brugal, J.-Ph., Beauval, C., Castel, J.C., Costamagno, S., Coumont, M.P., Fournier, J., Kuntz, D., 2013. Les Peuplements mammaliens au Pléistocène moyen et supérieur en Quercy. In: Settlement Dynamics and Environment Resources in the Palaeolithic of Southwest France: the Case of the Quercy Region. Proceedings of the XVth Congress of IUSPP, Session, vol. 61, pp. $145 \mathrm{e} 158$

Cahen, D., Karlin, C., Keeley, L.H., Van Noten, F., 1980. Méthodes d'analyse technique, spatiale et fonctionnelle d'ensembles lithiques. Helinium Wetteren 20 (3), 209-259.
Chalard, P., Faivre, J.- Ph., Jarry, M., Jaubert, J., Mourre, V., Turq, A., 2007. Espaces du Paléolithique moyen. Témoins d'utilisation de silex allochtones en Quercy (France). Un siècle de discours scientifique en Préhistoire. In: Actes du XXVIe Congrès Préhistorique de France, Congrès du Centenaire de la Société préhistorique Française, Avignon, 21-25 France, Congres du Centenaire de 3 .
septembre 2004, vol III, pp. 217-235.

Conard, N.J., 1992. Tonchesberg and its Position in the Paleolithic of Northern Europe. In Monograph 20. R6misch-Germanisches Zentralmuseum Series.

Coumont, M.-P., 2005. Taphonomie préhistorique: mammifêres fossils en contexte naturel, les avens pièges, apports pour l'étude des archéofaunes (Ph.D. thesis). Université Aix-

Marseille 1, France.
Delagnes, A., 1992. L'organisation de la production lithique au Paléolithique moyen: approche echnologique à partir de l'étude des industries de La Chaise-de- Vouthon (Charente)

Delagnes, A., 2000. Blade production during the Middle Paleolithic in Northwestern Europe Acta Anthropologica Sinica 19, 181-188.

Delagnes, A., Rendu, W., 2011. Shifts in Neandertal mobility, technology and sub- sistence strategies in western France. Journal of Archaeological Science 38 (8), 1771-1783.

Delagnes, A., Jaubert, J., Meignen, L., 2007. Les technocomplexes du Paléolithique moyen en Europe occidentale dans leur cadre diachronique et géographique. In: Les néandertaliens: biologie et cultures, pp. 213-229.

Depaepe, P., 2002. Le Paleolithique moyen de vallée de la Vanne (Yonne): matières premières, industries lithiques et occupations humaines (unpublished Ph.D.). Université Lille 1, industries lithiques et occe
Villeneuve-d'Ascq, France.

Deschamps, M., in press. Late Middle Palaeolithic assemblages with flake cleavers in the western Pyrenees: the Vasconian reconsidered. Quaternary International.

Detrain, L., Kervazo, B., Aubry, T., Bourguignon, L., Guadelli, J.L., Marcon, V., Teillet, P., 1991 Agrandissement du Musée national de Préhistoire des Eyzies. Résultats préliminaires des fouilles de sauvetage. Paléo 3 (1), 75-91.

Dibble, H.L., 1984. Interpreting typological variation of Middle Paleolithic scrapers: function, style, or sequence of reduction? Journal of Field Archaeology 11,431-436.

Dibble, H.L., 1987. Reduction sequences in the manufacture of Mousterian implements of France. In: Soffer, O. (Ed.), The Pleistocene of the Old World: Regional Perspectives. Plenum, New York, pp. 33-45.

Dibble, H.L., 1995. Middle Paleolithic scraper reduction: background, clarification, an review of evidence to data. Journal of Archaeological Method and Theory, 2 (4), 299 368.

Dibble, H.L., Bar-Yosef, O., 1995. The Definition and Interpretation of Levallois Technology (No. 23). Prehistory Press.

Dibble, H.L., Rezek, Z., 2009. Introducing a new experimental design for controlled studies of flake formation: results for exterior platform angle, platform depth, angle of blow, velocity, and force. Journal of Archaeological Science 36 (9), 1945-1954.

Dibble, H.L., Rolland, N., 1992. On assemblage variability in the Middle Palaeolithic of Western Europe: history, perspectives and a new synthesis. In: Dibble, H.-L., Mellars, P.-A. (Eds.), The Middle Palaeolithic: Adaptation, Behavior, and Variability University of Pennsylvania, University Museum Monographs n ${ }^{\circ}$ 72, Philadelphia, pp. 1-28.

Dibble, H.L., Lenoir, M., 1995. The Middle Paleolithic Site of Combe-Capelle Bas (France), vol. 91. UPenn Museum of Archaeology, 386 p.

Discamps, E., Jaubert, J., Bachellerie, F., 2011. Human choices and environmental constraints: deciphering the variability of large game procurement from Mousterian to Aurignacian times (MIS 5-3) in southwestern France. Quaternary Science Reviews 30,2755-2775. http://dx.doi.org/10.1016/j.quascirev.2011.06.009.

Faivre, J.-Ph., 2003. Le façonnage au Paléolithique moyen: témoignages de flexibilité opératoire dans le techno-complexe Moustérien de tradition acheuléenne. DEA de l'Université de

Faivre, J.-Ph., 2004. L'industrie lithique moustérienne du niveau G7 des Fieux (Miers, Lot): des matériaux, des schémas opératoires, un même objectif. Paléo 16, 71-90.

Faivre, J.-Ph., 2006. L'industrie moustérienne du niveau Ks (locus 1) des Fieux (Miers, Lot): mobilité humaine et diversité des compétences techniques. Bulletin de la Sociéte Préhistorique Française 103 (1), 17-32.

Faivre, J.-Ph., 2008. Organisation techno-économique des systèmes de production dans le Paléolithique moyen récent du Nord-est Aquitain: Combe-Grenal et les Fieux (Doctoral dissertation, Bordeaux 1).

Faivre, J.-Ph., 2011. Organisation techno-économique des systèmes de production dans le Paléolithique moyen récent du nord-est aquitain: Combe-Grenal et les Fieux. In: BAR International Series, vol. 2280, p. 244.

Faivre, J.-Ph., 2012. A material anecdote but technical reality: bladelet and small blade production during the recent Middle Paleolithic at Combe-Grenal rock shelter. Lithic Technology 37 (1), 5-25.

Faivre, J.-Ph., Turq, A., Bourguignon, L., Bismuth, Th., Colonge, D., Demars, P.-Y., Jarry, M. aubert, J., 2013. Le Paléolithique moyen du Quercy; comportements technoeconomiques et variabilités des productions lithiques. In: Jarry, M., Brugal, J.-Ph., Ferrie C. (Eds.), Modalités d'occupations et exploitation des milieux au Paléolithique dans le Sud-Ouest de la France: l'exemple du Quercy Actes du Colloque organise dans le cadre du XVlème Congrès de l'UISPP (Lisbon, September 2006). Supplement 5, Paléo, pp. 197 235.

Faivre, J.- Ph., Discamps, E., Gravina, B., Turq, A., Guadelli, J.L., Lenoir, M., 2014. The contribution of lithic production systems to the interpretation of Mousterian industrial variability in south-western France: the example of Combe-Grenal (Dordogne, France). Quaternary International 350, 227-240. 
Fernandes, P. 2012. Itinéraires et transformations du silex: une pétroarchéologie refondée, application au Paléolithique moyen (Doctoral dissertation, Bordeaux 1).

Geneste, J.-M., 1985. Analyse lithique d'industries moustériennes du Périgord: une approche technologique du comportement des groupes humains au Paléolithique moyen (Phd, unpublished). Université Bordeaux I, Bordeaux.

Geneste, J.-M., 1988. Les industries de la Grotte Vaufrey: technologie du débitage, économie et circulation de la matière première lithique. In: La Grotte Vaufrey a Cenac et Saint-Julien (Dordogne), pp. 441-518.

Geneste, J-M 1991. Systèmes techniques de productions lithiques: variations technoéconomiques dans les processus de réalisation des outillages paléolithiques. Technique et Culture 17-18, 1-36.

Gravina, B., Discamps, E., 2015. MTA-B or not to be? Recycled bifaces and shifting hunting strategies at Le Moustier and their implication for the late Middle Palaeolithic in southwestern France. Journal of Human Evolution 84, 83-98.

Gravina, B., in press. Intra-level technological change and its implications for Mousterian assemblage variability. The example of Le Moustier, layer G. Quaternary International.

Hiscock, P., Turq, A., Faivre, J.-Ph, Bourguignon, L., 2009. Quina procurement and tool production. In: Blades, B., Adams, B. (Eds.), Lithic Materials and Paleolithic Societies. Blackwell Edition, pp. 232-246.

Holdaway, S., Douglass, M., 2011. A twenty-first century archaeology of stone artifacts. Journal of Archaeological Method and Theory 19, 101-131.

Inizan, M.L., Reduron-Ballinger, M., Roche, H., 1999. Technology and Terminology of Knapped Stone: Followed by a Multilingual Vocabulary Arabic, English, French, German, Greek, Italian, Portuguese, Spanish, vol. 5. Cercle de Recherches et d'Etudes Préhistoriques.

Jaubert, J., 2012. Les archéo-séquences du Paléolithique moyen du Sud-Ouest de la France: quel bilan un quart de siècle après François Bordes? In: Delpech, F., Jaubert, J. (Eds.), François Bordes et la Préhistoire. Editions du CTHS, Documents préhistoriques 29, Paris, pp. $235-253$

Jaubert, J., Mourre, V., 1996. Coudoulous, Le Rescoundudou, Mauran: diversité des matières premières et variabilité des schémas de production d'éclats. In: Bietti, A., Grimaldi, S. (Eds.), Reduction Processe ( Chaînes opératoires ») for the European Mousterian, Proceeding of the International Round Table, Rome, May 26-28 1995, Quaternaria Nova VI, pp. 313-341.

Jaubert, J., Bordes, J.G., Discamps, E., Gravina, B., 2011. A new look at the end of the Middle Palaeolithic sequence in southwestern France. In: International Symposium Characteristic Features of the Middle to Upper Paleolithic Transition in Eurasia: Development of Culture and Evolution of Homo Species. Asian Palaeolithic Association, pp. 102-115.

Kozłowsky, J., 2001. Origin and evolution of blade technologies in the Middle and Early Upper Paleolithic. Mediterranean Archaeology and Archaeometry 1, 8-18.

Kuhn, S.L., Bietti, A., 2000. The late Middle and Early Upper Paleolithic in Italy. In: The Geography of Neanderthal and Moderns Humans in Europe and the Greater Mediterranean, pp. 49-76.

Lemorini, C., Peresani, M., Rossetti, P., Malerba, G., Giacobini, G., 2003. Technomorphological and use-wear functional analysis: an integrated approach to the study of a discoid industry. In: Bar International Series, vol. 1120, pp. 257-275.

Lenoir, M., Turq, A., 1995. Recurrent centripetal debitage (Levallois and Discoidal): continuity or discontinuity. In: Dibble, H.-L., Bar-Yosef, O. (Eds.), The Definition and Interprétation of Levallois Technology, Monographs in World Archaeology, vol. 23. Prehistory Press, Madison, Wisconsin, pp. 249-255.

Locht, J.-L., 2003. L'industrie lithique du gisement de Beauvais (Oise, France): objectifs et variabilite du debitage discoide. In: Bar International Series, vol. 1120, pp. 193-208.

Locht, J.-L., Swinnen, C., 1994. Le débitage discoïde du gisement de Beauvais (Oise): aspect de la chaîne opératoire au travers de quelques remontages. Paléo 6, 89-104.

Lorenzo Martinez, M., Bordes, J.G., Jaubert, J., 2014. L'industrie lithique du Paléolithique moyen récent de Roc de Combe (Payrignac, Lot, France), un nouvel exemple de Moustérien Discoïde à denticulés. Paléo $25,101-124$

Lycett, S.J., Eren, M.I., 2013. Levallois economics: an examination of 'waste' pro- duction in experimentally produced Levallois reduction sequences. Journal of Archaeological Science 40 (5), 2384-2392.

Martinez, K., Olle, A., Sala, R., Verges, J.M., 2003. Discoid Technology and Use-wear Analysis from Abric Romaní. In: BAR International Series, vol. 1120, pp. 241-256.

Mcpherron, S.P., Dibble, H.L., 1999. The lithic assemblages of Pech de l'Azé IV (Dordogne, France). Préhistoire Européenne 15, 9-43.

Mellars, P.A., 1965. Sequence and development of Mousterian traditions in south-western France. Nature 205, 626-627.

Mellars, P.A., 1970. The chronology of Mousterian industries in the Périgord region of southwest France. Proceedings of the Prehistoric Society (New Series) 35, 134-171.

Mellars, P.A., 1996. The Neanderthal Legacy: an Archaeological Perspective from Western Europe. Princeton University Press.

Monnier, G., 2006. The Lower/Middle Paleolithic periodization in western Europe: an evaluation. Current Anthropology 47, 709-744

Monnier, G.F., Missal, K., 2014. Another Mousterian Debate? Bordian facies, chaîne opératoire technocomplexes, and patterns of lithic variability in the western European Middle and Upper Pleistocene. Quaternary International 350, 59-83.
Ortega, I., Locht, J.-L., Soressi, M., Rios, J., Bourguignon, L., Blaser, F., Grigoletto, F., Sellier, N., 2013. La producción laminar durante el Paleolítico medio en el norte y el sur-oeste de N., 2013. La producción laminar durante el Paleolitico medio en el norte y el sur-oeste de Francia: el aporte de la experimentación. In: Palomo, A., Piqué, R., Terradas, X. (Eds.), Experimentación en arqueología. Estudio y difusión del pasado, Serie
MAC-Girona 25.1, Girona 2013, ISBN 978-84- 393-9024-4, pp. 219-228.

Otte, M., 1994. Rocourt (Liège, Belgique): industrie laminaire ancienne. In: Revillion, S., Tuffreau, A. (Eds.), Les industries laminaires au Paléolithique Moyen, Dossier de Tuffreau, A. (Eds.), Les industries laminaires au
Documentation Archéologique, vol. 18, pp. 180-186.

Pasty, J.-F., 2000. Le gisement paléolithique moyen des Meillers (Allier): un exemple de la variabilité du débitage discoïde. Bulletin de la Société Préhistorique Française 97 (2), 165190.

Peresani, M., 2003. Discoid Lithic Technology. In: BAR International Series, vol. 1120.

Perinotto, C., 2015. Techno économie et taphonomie spatiale des industries moustériennes de l'abri Caminade (La Canéda, Dordogne). In: Mémoire de Master 2. Université de Bordeaux.

Rendu, W., Beauval, C., Crevecoeur, I., Bayle, P., Balzeau, A., Bismuth, T., et al., 2014. Evidence supporting an intentional Neandertal burial at La Chapelle-aux-Saints. Proceedings of the National Academy of Sciences 111 (1), 81-86.

Revillion, S., 1995. Technologie du débitage laminaire au Paléolithique moyen en Europe septentrionale: état de la question. Bulletin de la Société Préhistorique Française 95, 425441.

Rios Garaizar, J., 2007. Industria litica y sociedad en la transición del Paleolítico medio al superior en torno al golfo de Bizkaia (Thèse de doctorat). Universitédes Cantabres, Santander, p. 561 2006 .

Rolland, N., Dibble, H.L., 1990. A new synthesis of Middle Paleolithic assemblage variability. American Antiquity 55 (3), 480-499.

Roussel, M., Bourguignon, L., Soressi, M., 2009. La percussion à la pierre tendre au Paléolithique moyen: intentionnalité ou opportunisme. Expérimentation et analyse du matériel de " Chez-Pinaud », Jonzac (Charente-Maritime). Bulletin de la Société Préhistorique Française 106, 219-238.

Scerri, E.M.L., Gravina, B., Blinkhorn, J., Delagnes, A., 2015. Can lithic attribute analyses identify discrete reduction trajectories? A quantitative study using refitted lithic sets. Journal of Archaeological Method and Theory. http:// dx.doi.org/10.1007/s10816-015-9255-x.

Soressi, M., 2002. Le Moustérien de tradition acheuléenne du sud-ouest de la France. Discussion sur la signification du faciès à partir de l'étude comparée de quatre sites: Pech-de-l'Azé I, Le Moustier, La Rochette et la Grotte XVI (Doctoral dissertation, Bordeaux 1).

Soressi, M., Geneste, J.M., 2011. Special issue: reduction sequence, chaîne opératoire, and other methods: the epistemologies of different approaches to lithic analysis the history and efficacy of the chaîne operatoire approach to lithic analysis: studying techniques to reveal past societies in an evolutionary perspective. PaleoAnthropology 334,350 .

Thiébaut, C., Mourre, V., Turq, A., 2009. Diversité des matériaux et diversité des schémas de production au sein de l'industrie moustérienne de la couche K des Fieux (Miers, Lot). Bulletin de la Société préhistorique française 239-256.

Tixier, J., 1978. Notice sur les travaux scientifiques de J. Tixier (Thèse d'Etat). Université de Paris $\mathrm{X}$, Nanterre, p. 118

Tixier, J., Inizan, M.-L., Roche, H., 1980. Préhistoire de la pierre taillée 1, terminologie et technologie. In: Cercle de Recherches et d'Etudes Préhistoriques. Antibes, p. 120 ill.

Tostevin, G.B., 2003. A Quest for Antecedents: a Comparison of the Terminal Middle Palaeolithic and Early Upper Palaeolithic of the Levant. More than Meets the Eye: Studies on Uppe Palaeolithic Diversity in the Near East. Oxbow Press, Oxford, pp. 54-67.

Tostevin, G.B., 2012. Seeing Lithics.

Turq, A., 1989. Approche technologique et économique du faciès Moustérien de type Quina: étude préliminaire. Bulletin de la Société préhistorique française 244-256.

Turq, A., 1990. Exploitation du milieu minéral: technologie, économie et circulation des silex. In: Jaubert, J., Lorblanchet, M., Laville, H., Slott-Moller, R., Turq, A., Brugal, J.-P.H. (Eds.), Les chasseurs d'Aurochs de La Borde. Un site du Paléolithique moyen (Livernon, Lot). Ed. Maison des sciences de l'Homme, Paris, pp. 103-115 ill. Documents d'Archéologie Française $\mathrm{n}^{\circ} 27$.

Turq, A., 1992. Le Paléolithique inférieur et moyen entre les vallées de la Dordogne et du Lot (Doctoral dissertation).

Turq, A., 2000. Paléolithique inférieur et moyen entre Dordogne et Lot. Paléo Supplément $\mathrm{n}^{\circ} 2$ 456

Turq, A., Dibble, H.L, Faivre, J.-Ph., Goldberg, P., McPherron, S.P.,Sandgathe, D., 2009. Le Moustérien du Périgord Noir: quoi de neuf? In: Jaubert, J., Bordes, J.-G., Ortega, I. (Dirs.), Les sociétés du Paléolithique dans un Grand Sud-Ouest de la France: nouveaux gisements, nouveaux résultats, nouvelles méthodes, Mémoire XLVII de la Société Préhistorique Française, pp. 83-93.

Turq, A., Roebroeks, W., Bourguignon, L., Faivre, J.-Ph, 2013. The fragmented char- acter of Middle Palaeolithic stone tool technology. Journal of Human Evolution 65 (5), 641-655.

Turq, A., Faivre, J.-Ph, Gravina, B., Bourguignon, L., in press. Building Models of Neanderthal Territories: an Example from the Northeast Aquitaine Basin of Southwestern France.

Van Peer, P., 1992. The Levallois Reduction Strategy (No. 13). Prehistory Press.

Will, M., Bader, G.D., Conard, N.J., 2014. Characterizing the late Pleistocene MSA lithic technology of Sibudu, KwaZulu-Natal, South Africa. PLoS One 9. http:// dx.doi.org/10.1371/journal.pone.0098359. 